\title{
Pharmacological targeting of the HIF hydroxylases - a new field in medicine development
}

Mun Chiang Chan ${ }^{\mathrm{a}}$, James P. Holt-Martyn ${ }^{\mathrm{b}}$, Christopher J. Schofield ${ }^{\mathrm{b} *}$ and Peter J. Ratcliffe ${ }^{\mathrm{a} *}$.

${ }^{\text {a }}$ Centre for Cellular and Molecular Physiology, Nuffield Department of Medicine, University of Oxford, Roosevelt Drive, Oxford OX3 7BN, United Kingdom

${ }^{\mathrm{b}}$ Chemistry Research Laboratory, Department of Chemistry, University of Oxford, 12 Mansfield Road, Oxford, OX1 3TA, United Kingdom

* Corresponding authors.

Email addresses: andrewc@well.ox.ac.uk (M.C. Chan), james.holt-martyn@chem.ox.ac.uk (J.P. HoltMartyn), christopher.schofield@chem.ox.ac.uk (C.J. Schofield), pjr@well.ox.ac.uk (P.J. Ratcliffe).

\begin{abstract}
In human cells oxygen levels are 'sensed' by a set of ferrous iron and 2-oxoglutarate dependent dioxygenases. These enzymes regulate a broad range of cellular and systemic responses to hypoxia by catalysing the post-translational hydroxylation of specific residues in the alpha subunits of hypoxia inducible factor (HIF) transcriptional complexes. The HIF hydroxylases are now the subject of pharmaceutical targeting by small molecule inhibitors that aim to activate or augment the endogenous HIF transcriptional response for the treatment of anaemia and other hypoxic human diseases. Here we consider the rationale for this therapeutic strategy from the biochemical, biological and medical perspectives. We outline structural and mechanistic considerations that are relevant to the design of HIF hydroxylase inhibitors, including likely determinants of specificity, and review published reports on their activity in pre-clinical models and clinical trials.
\end{abstract}

\section{Keywords}

Hypoxia, HIF prolyl hydroxylases, inhibitor, oxygen sensing, ㅂypoxia Inducible Factor (HIF), HIF hydroxylases. 


\section{Introduction}

A wide range of inducible signalling systems operate in order to protect human cells from damaging stresses. Such systems are attractive for the development of drugs that seek to ameliorate injury or enhance repair by augmenting the natural protective response. Here we review developments in our understanding of the transcriptional responses to hypoxia from this perspective, focusing on progress towards therapeutic activation of hypoxia inducible factor (HIF) by inhibition of the HIF prolyl hydroxylase enzymes that signal the availability of oxygen to HIF.

HIF is a basic-helix-loop-helix-PAS domain transcription factor that binds to hypoxia response elements in DNA as an alpha/beta heterodimer (Wang et al., 1995; Wu et al., 2015). Regulation by oxygen is mediated by the alpha subunits, via the post-translational hydroxylation of specific amino acid residues. In the human system, prolyl hydroxylation at $\underline{N}$ - and $\underline{\mathcal{C}}$-terminal sites within a central oxygen-dependent degradation domain (NODD, CODD) promotes association with the von HippelLindau ( $p V H L$ ) ubiquitin E3 ligase complex, followed by degradation by the ubiquitin-proteasome pathway (Figure 1) (Ivan et al., 2001; Jaakkola et al., 2001; Maxwell et al., 1999). Asparaginyl hydroxylation, at a single site within the $C$-terminal activation domain (CAD) of HIF- $\alpha$ subunits, downregulates transcriptional activity by blocking the recruitment of transcriptional co-activator proteins (Dames et al., 2002; Freedman et al., 2002; Lando et al., 2002b; McNeill et al., 2002). In humans, HIF prolyl hydroxylation is catalysed by three closely related dioxygenases, PHD (prolyl hydroxylase domain) 1, 2 and 3 (otherwise known as EGLN2, 1 and 3) (Bruick et al., 2001; Epstein et al., 2001). HIF asparaginyl hydroxylation is catalysed by FIH (factor inhibiting $\underline{H}$ IF) (Hewitson et al., 2002; Lando et al., 2002a). The PHDs and FIH both belong to the superfamily of ferrous iron and 2oxoglutarate dependent oxygenases (2OG oxygenases) (Aik et al., 2015; Hausinger, 2004). Like other $20 \mathrm{G}$ oxygenases, the HIF hydroxylases couple oxidative decarboxylation of $20 \mathrm{G}$ to hydroxylation (of HIF- $\alpha$ ), with concomitant production of succinate and carbon dioxide (Hausinger, 2004). In hypoxic cells, HIF hydroxylase activity is suppressed, allowing HIF- $\alpha$ to escape proteolysis and assemble into an active transcriptional complex. Given the role of hypoxia in many human diseases, this direct connection between oxygenase-dependent catalysis and the physiological response to hypoxia 
suggested that medicinal modulation of HIF hydroxylase activity should have therapeutic potential - a proposal supported by recent clinical studies (see below).

The HIF system was first identified though studies of one of the most sensitive homeostatic responses to hypoxia, induction of the haematopoietic growth factor erythropoietin by reduced blood oxygen availability (Semenza et al., 1992). However it rapidly became apparent that this response was part of a widespread response to cellular hypoxia (Maxwell et al., 1993b). Pan-genomic studies have revealed the existence of thousands of direct HIF transcriptional targets across the human genome (for review, see (Schödel et al., 2013)). Direct transcriptional effects are amplified by the action of HIF on numerous secondary transcriptional cascades, extensive non-coding RNA networks and multiple aspects of RNA processing/translational control (Choudhry et al., 2014; Kulshreshtha et al., 2007; Uniacke et al., 2012). Overall, these pathways have multiple cellular and systemic actions that support oxygen homeostasis, either through enhancement of oxygen delivery (erythropoiesis, angiogenesis, ventilatory and vasomotor controls) or through reduction in oxygen demands (reprogramming of energy metabolism, cytostasis and cell survival decisions), for review see (Masson et al., 2014; Pouyssegur et al., 2006; Prabhakar et al., 2012). Reflecting these very widespread functions, the HIF pathway has been considered as the master regulator of oxygen homeostasis. However the diversity of HIF target genes and the phenotypes associated with inactivation of the system, suggest that HIF pathways have even more extensive biological actions. For instance, HIF has multiple effects on immune and inflammatory signalling (for review see (Eltzschig et al., 2014; Eltzschig et al., 2011a; Nizet et al., 2009)). These actions might reflect a hitherto unrecognised physiology of hypoxia, or (since HIF can apparently also be activated by non-hypoxic stimuli such as cytokines and growth factors (for review see (Eltzschig et al., 2014; Eltzschig and Carmeliet, 2011a; Nizet and Johnson, 2009)), subversion of the pathway for functions unconnected with oxygen homeostasis. The HIF system represents an exciting target for the development of new therapeutics. However, the complexity and widespread nature of the HIF related pathways presents a challenge in predicting drug action. A wide range of therapeutic approaches have been proposed targeting different points in the HIF system (Figure 1). In this review we focus on the most advanced of the current therapeutic developments, activation of HIF by inhibition of the HIF prolyl hydroxylases. 
The fundamental premise underlying this approach is that, in disease, activation of the HIF transcriptional cascade by endogenous hypoxia is suboptimal (for at least some components of the response), and that this can be augmented by additional pharmacological inhibition. For instance, in the anaemia associated with renal disease, erythropoietin (Epo) production is reduced due to poorly understood changes in the renal interstitium (see review (Haase, 2013)). The aim of HIF prolyl hydroxylase inhibition treatment for anaemia is to augment native erythropoietin production in the diseased kidneys or in the liver. Similarly, in ischaemic tissues, poorly understood cytoprotective and reparative responses are promoted, at least in part, by the endogenous activation of HIF; pharmacological activation may augment this defence, for instance through actions on angiogenesis and metabolic reprogramming. In other diseases, the induction of specific HIF functions (e.g. improved epithelial barrier function, enhanced stem cell behaviour, or immune cell modulation) may be of value. However, the diversity of the roles of HIF strongly suggests that global activation of all components of the system is unlikely to be universally beneficial. Thus, one challenge facing the clinical therapeutic development of molecules that augment the natural hypoxic response is how to achieve the most desirable spectrum of HIF pathway activation in a given clinical condition. Several general approaches have the potential to impact on the problem.

Firstly, specificity may be intrinsic to the physiological response or disease process. For instance, the induction of erythropoietin production is one of the most sensitive responses to physiological hypoxia. It is possible that this might intrinsically enable a (partially) specific response to HIF prolyl hydroxylase inhibition. Similarly, in ischaemic tissues, it is possible that tissue hypoxia might sensitise cells to pharmacological HIF prolyl hydroxylase inhibition, so enabling a selective response in the target tissue. Secondly, specific action might be achieved through pharmacokinetic and pharmacodynamic considerations. Drugs are normally differentially distributed across tissues and often can achieve their highest tissue concentrations in liver and kidney, the main organs that produce erythropoietin. Thus molecules that concentrate in, or which are targeted to, these organs may be more effective in the stimulation of erythropoietin production, as opposed to other actions (for reviews, see (Myllyharju, 2013; Schofield et al., 2004)). Thirdly, selective inhibition of one or two of the three human HIF prolyl 
hydroxylases, or even differences in non-selective activity on other $20 \mathrm{G}$ oxygenases, may hold the key to effective differentiation of clinical effects. PHD2 is the most abundant HIF prolyl hydroxylase in most tissues and therefore is the most important enzyme in regulating many outputs of the HIF system (Appelhoff et al., 2004; Berra et al., 2003). Nevertheless PHD1 and PHD3 make a relatively greater contribution to the regulation of HIF-2 $\alpha$ versus HIF-1 $\alpha$ (Appelhoff et al., 2004). HIF-1 $\alpha$ and HIF-2 $\alpha$ isoforms have distinct (though still incompletely understood) physiological roles, including apparently specific upregulation of erythropoietin production by HIF-2 $\alpha$. Interestingly, in certain circumstances HIF-1 $\alpha$ and HIF-2 $\alpha$ may even have opposing actions on some responses to hypoxia (for review, see (Keith et al., 2012)). Notably, PHD1 and 2 accept both NODD and CODD substrates, whereas PHD3 is highly selective for CODD (Epstein et al., 2001; Hirsila et al., 2003; Landazuri et al., 2006). Thus even moderately selective activity against different HIF prolyl hydroxylases may be clinically differentiating. The feasibility of targeting individual PHD isoform to upregulate specific HIF- $\alpha$ isoform is exemplified by a recent study of Akebia's compound, AKB-6899, an inhibitor that is reported to inhibit PHD3 preferentially, resulting in specific upregulation of HIF-2 $\alpha$ in murine bone marrow-derived macrophages (Roda et al., 2012). Differential modulation of FIH might also permit useful differentiation of HIF hydroxylase inhibitors, given that FIH has been demonstrated to modulate the expression of some but not all HIF target genes (Dayan et al., 2009; Dayan et al., 2006). Interestingly FIH has been reported to be more active with respect to hydroxylation of HIF-1 $\alpha$ CAD compared to HIF-2 $\alpha$ (Koivunen et al., 2004; Tarhonskaya et al., 2015). These observations suggest that combined inhibition of the PHDs and FIH might possibly be exploited as a strategy to selectively enhance activation of the HIF-1 $\alpha$ dependent transcriptional programme.

Hypoxia itself is a non-specific inhibitor of not just the HIF prolyl and asparaginyl hydroxylases, but also, potentially, of any of the $\sim 60$ human 206 oxygenases. Such enzymes catalyse a range of biological oxidations, including nucleic acid and protein (histone) demethylations and hydroxylations that affect gene expression, and hence have the potential to modulate components of the HIF transcriptional cascade (Hausinger, 2004; Klose et al., 2006; Klose et al., 2007; Loenarz et al., 2008). At present it is unclear to what extent this occurs. Nevertheless, a number of $20 \mathrm{G}$ oxygenases, including chromatin modifying enzymes, are themselves targets of HIF (Beyer et al., 2008; Pollard et 
al., 2008; Xia et al., 2009), suggesting a role in response to hypoxia. It is thus possible that different inhibitors with activities against both HIF hydroxylases, and at least some other 20G oxygenases, could have clinically useful differential actions on hypoxia signalling pathways.

Thus, although the definition of the HIF hydroxylases as targets for drug development has opened an exciting new area of experimental medicine, there remain significant uncertainties as to the best therapeutic strategies. Against this background we will review progress in HIF hydroxylase development to date including the structural and mechanistic considerations that underpin rational inhibitor design.

\section{Overview of the Structures, and Mechanisms of HIF hydroxylases and Possible Modes of} Inhibition

To place studies on the therapeutic modulation of the HIF hydroxylases (including the potential for specific inhibition) in context, we will first summarise relevant general structural and mechanistic knowledge of the $20 \mathrm{G}$ oxygenase superfamily, including precedents for pharmaceutical targeting. For more detailed reviews on $20 \mathrm{G}$ oxygenase inhibition and biochemistry see (Aik et al., 2015; Hausinger, 2004; Hausinger, 2015; McDonough et al., 2010; Rose et al., 2011; Thinnes et al., 2014).

HIF hydroxylases are non-haem iron utilising redox enzymes, which, as a general type, are well precedented as drug targets, perhaps most notably with respect to cyclooxygenase inhibition (Simmons et al., 2004). At the time of discovery of the HIF hydroxylases, several 20 G oxygenases (and closely related enzymes) had already been successfully targeted. For instance, $\boldsymbol{\gamma}$-butyrobetaine hydroxylase (BBOX1) had been targeted for therapeutic inhibition following myocardial infarction, though the precise mechanism of action of the BBOX1 inhibitors is unclear (Leung et al., 2010b; Rose et al., 2011; Simkhovich et al., 1988). Pioneering work on collagen prolyl hydroxylases established the feasibility of prolyl hydroxylase inhibition by small molecules (Nwogu et al., 2001; Sharir et al., 1993; Tschank et al., 1991). Inhibitors of another 2-oxo acid dioxygenase, p-hydroxyphenylpyruvate dioxygenase (HPPD) are used in the treatment of type III tyrosinemia (Lindstedt et al., 1992; Lock et al., 1998); HPPD is not a $20 \mathrm{G}$ oxygenase, but oxidises a 2-oxo acid tyrosine-containing metabolite 
(Lock et al., 1998; Moran, 2005). 2-oxo acid dioxygenases are also important targets in agrochemistry; including $20 \mathrm{G}$ oxygenases involved in gibberellin biosynthesis (Rose et al., 2011) and plant HPPD (Moran, 2005). It was also known that aspects of the hypoxic response could be induced by treatment with cobalt (II) ions (Schuster et al., 1989) or with non-specific metal chelators (e.g. desferrioxamine, DFO (Wang et al., 1993)). Indeed, cobalt (II) ions were once used for the treatment of anaemia (Berk et al., 1949; Wolf et al., 1954); both these treatments are likely to be mediated by HIF hydroxylase (PHD) inhibition, i.e. by competition of cobalt (II) with ferrous iron ions for binding to the active sites, or by removal of ferrous iron by the chelators (Epstein et al., 2001). Thus, following the discovery of the roles of the HIF hydroxylases in the hypoxic response, there was a good indication that they, and in particular the PHDs, might be therapeutically tractable drug targets.

The $20 \mathrm{G}$ oxygenases are widely distributed in aerobes (though likely not archaea) where they catalyse a very wide range of oxidative reactions (Aik et al., 2015; Hausinger, 2004; Hausinger, 2015; Loenarz et al., 2011b; Noma et al., 2010). In animals, reactions identified to date are limited to hydroxylations and $\mathrm{N}$-methyl group demethylations, proceeding via initial hydroxylation of the methyl group (Klose and Zhang, 2007; Thalhammer et al., 2012; Thinnes et al., 2014). To date all $20 \mathrm{G}$ oxygenases, including the PHDs and FIH, have been found to contain a modified double-stranded $\beta$-helix protein (DSBH) fold; in different research fields, this fold has also been referred to as a cupin, jelly-roll, or JmjC motif (Aik et al., 2012; Aik et al., 2015). The DSBH fold supports three highly, but not exclusively, conserved iron binding residues, which form an HXD/E...H metal chelating motif (Aik et al., 2012; Aik et al., 2015). The HXD motif is often located on a distorted $\beta$-strand; in a few cases, including at least one human enzyme, the latter histidine of the HXD/E...H motif is not required (Lancaster et al., 2004).

A large body of evidence from kinetic, spectroscopic and crystallographic analyses supports a consensus catalytic mechanism for the PHDs and FIH as occurs for other studied $20 \mathrm{OG}$ oxygenases (Figure 2). Binding of $20 \mathrm{G}$ to a (normally) tri-coordinated iron is sequentially followed by binding of the prime (e.g. HIF- $\alpha$ ) substrate and, finally, oxygen (Aik et al., 2015; Hausinger, 2004; Hausinger, 2015; Noma et al., 2010; Rose et al., 2011; Thinnes et al., 2014; Zhou et al., 2001). At least in some cases, substrate binding reduces the metal coordination of a water molecule in the octahedrally coordinated 
metal 20 complex, freeing up a vacant coordination position for binding to oxygen. Oxidative decarboxylation of $20 \mathrm{G}$ then yields a ferryl $\left(\mathrm{Fe}^{(\mathrm{IV})}=0\right)$ intermediate that effects substrate oxidation (hydroxylation for the HIF- $\alpha$ substrates); oxidised product release is then followed by that of succinate, with rehydration of the metal centre (Hausinger, 2004; Krebs et al., 2007). The rates of individual steps in the mechanism vary. Notably, in the case of the PHDs, the $\mathrm{Fe}^{(\mathrm{IV})}=\mathrm{O}$ intermediate has not been observed spectroscopically, consistent with hydroxylation of the HIF- $\alpha$ substrate by this intermediate not being rate limiting in PHD catalysis (Flashman et al., 2010; Tarhonskaya et al., 2015). In contrast for PHD2, there is evidence that binding of oxygen to the 2OG substrate complex coupled to displacement of a metal bound water in the enzyme-substrate complex is rate limiting in catalysis (Flagg et al., 2012; Flashman et al., 2010; Pektas et al., 2015; Tarhonskaya et al., 2014a; Tarhonskaya et al., 2015), a property consistent with the oxygen sensing role of the PHDs. Another distinguishing feature of PHD2 is that it forms an unusually stable enzyme Fe(II) $20 \mathrm{G}$ complex (McNeill et al., 2005b). $20 \mathrm{G}$ oxygenases often oxidise $20 \mathrm{G}$ to succinate in the absence of substrate, albeit at a reduced rate. Since such uncoupled activity may leave the enzyme in an oxidised inactive form, this process has the potential to alter the effective kinetics with respect to dioxygen. As with its slow reaction with oxygen, the unusually stable enzyme Fe(II) $20 \mathrm{G}$ complex is proposed to enable the PHDs (at least as shown by work with PHD2) to respond specifically to dioxygen levels and hence act as an oxygen sensor (Flashman et al., 2010; Tarhonskaya et al., 2014a).

The mode of action of most 'current generation' HIF prolyl hydroxylase inhibitors involves $20 \mathrm{G}$ competition (see below and Figure 2) (Rose et al., 2011). As shown by spectroscopic and multiple crystal structures, the 2-oxoacid element of $20 \mathrm{G}$ binds in a bi-dentate manner to the iron via its 2-oxo oxygen and one of its C-1 carboxylate oxygens (Aik et al., 2012; Aik et al., 2015; Hausinger, 2004; McDonough et al., 2006; Rose et al., 2011). The methylene groups and C-5 carboxylate of $20 \mathrm{G}$ are bound in a pocket directed towards the interior of the protein fold. The C-5 carboxylate is bound by interactions with a basic residue - lysine in FIH (Dann et al., 2002) or arginine in the PHDs (McDonough et al., 2006), and at least one alcohol (Aik et al., 2012). Although the generic use of $20 \mathrm{G}$ as co-substrate raises issues for the design of selective $20 \mathrm{G}$ analogues, the mode of $20 \mathrm{G}$ 'side chain' binding is a subfamily characteristic (Aik et al., 2012)] suggesting that it can be exploited in inhibitor design 
(McDonough et al., 2005; Rose et al., 2011; Thinnes et al., 2014). It is also notable that there are considerable variations in the $\mathrm{K}_{\mathrm{m}}$ values for $20 \mathrm{G}$ for $20 \mathrm{G}$ oxygenases, a property that should be taken into consideration when predicting potencies of $20 \mathrm{G}$ competing inhibitors in cells. In addition, cosubstrate (2OG)/co-product (succinate) inhibition is commonly observed with $20 \mathrm{G}$ oxygenases. Intracellular levels of succinate and fumarate can be substantially elevated, particularly in certain cancer cells, and it has been proposed that inhibition of the PHDs by these endogenous inhibitors can induce the hypoxic response and promote cancer development (Hewitson et al., 2007a; Kawamura et al., 2011; Koivunen et al., 2007; Pollard et al., 2005; Selak et al., 2005). However, the pathophysiological relevance of such inhibition is unclear (Adam et al., 2011). This is also the case with partial inhibition (Kawamura et al., 2011; Tarhonskaya et al., 2014b), or even potentially activation (Koivunen et al., 2012) of the PHDs by 2-hydroxyglutarate levels which are elevated (with a concomitant decrease in $20 \mathrm{G}$ levels) by specific gain of function mutations of isocitrate dehydrogenases 1 and 2. Whatever the pathophysiological relevance of these findings, it is important to recognise that the potency of $20 \mathrm{G}$ competitive inhibition on the HIF hydroxylases may be affected by a variation in levels of 2-oxo acids and related metabolites in different cell types.

In contrast to the common use of $20 \mathrm{OG}$ and iron as co-substrate/co-factors, the ( $\sim 60)$ human $20 \mathrm{G}$ oxygenases oxidise a diverse range of prime substrates, including proteins, small-molecules, nucleic acids and lipids (Hausinger, 2004; McDonough et al., 2010; Thinnes et al., 2014). Consistent with this, they vary considerably more in their substrate binding modes than those of $20 \mathrm{G}$ and iron (Aik et al., 2012; McDonough et al., 2010). Substrate binding typically involves residues from $\beta 1$ and $\beta 2$ of the eight conserved strands of the core DSBH fold, as well as mobile elements and residues from the active site (Aik et al., 2012; McDonough et al., 2010). In the case of the PHDs, crystal structures of the catalytic domain of PHD2 with and without a HIF- $\alpha$ CODD peptide suggest that induced fit plays a crucial role in substrate binding during catalysis (Chowdhury et al., 2009). The CODD sequence binds as an extended loop on the surface of PHD2; a loop region located between $\beta 2$ - $\beta 3$ folds over the conserved LXXLAP motif of the HIF- $\alpha$-CODD substrate to completely enclose the target prolyl and adjacent residues (Figure 3A). Emerging results are revealing differences in the extent to which different types of PHD inhibitor that compete with $20 \mathrm{G}$ also compete with CODD for binding. 
Crystallographic analyses reveal that the binding of certain PHD inhibitors (e.g. Fibrogen's FG-2216, see below) at the PHD2 active site may also prevent the binding of HIF- $\alpha$-CODD substrate (Chowdhury et al., 2009), an observation supported by NMR (Nuclear Magnetic Resonance) studies (Leung et al., 2010a). It is important to note that although some inhibitors perturb the productive binding mode of the hydroxylated HIF- $\alpha$ proline residue and surrounding residues based on crystallographic analysis, they do not necessarily displace HIF- $\alpha$ CODD completely from binding. For example, the PHD inhibitor IOX2 is predicted to block the binding of HIF- $\alpha$-CODD substrate based on crystallographic analyses, but NMR studies indicate otherwise (Chan et al., 2015). This is a general caveat of crystallographic analyses, which do not always precisely reflect the solution binding mode as measured by NMR. For instance, in another study on a prolyl hydroxylase inhibitor structurally related to FG-2216, NMR revealed two modes of binding to PHD2 in the solution state, in contrast to the single binding mode in the crystal state (Poppe et al., 2009). Deeper knowledge of the dynamics of the protein-protein interactions involved in HIF- $\alpha$ substrate binding will be important in the development of PHD isoform and, potentially, NODD/CODD substrate selective inhibitors. In this regard, it is noticeable that the three PHD isoforms differ in their $N$-terminal regions, with PHD3 having the shortest $N$-terminal. PHD2, but not PHD1 or 3, contains a MYND type zinc finger which is highly conserved in PHD evolution (Loenarz et al., 2011a) and has been reported to enhance the inhibition of HIF by overexpressed PHD2 (Choi et al., 2005). These differences in the $N$-terminal region could conceivably provide a route to isoform-selective inhibition of the PHDs, although structural and mechanistic information is not yet available to assess this possibility. Interestingly, polymorphisms in the $\mathrm{N}$-terminal region of PHD2 are linked to adaptation to high altitude in the Tibetan population (Song et al., 2014). Since degradation of HIF- $\alpha$ isoforms is differently dependent on NODD and CODD hydroxylations, inhibitors with differential effects on HIF- $\alpha$ substrate binding may enable the HIF response to be tuned to generate different biological outputs. It is notable that multiple non-HIF- $\alpha$ substrates have been reported for the PHDs (Anderson et al., 2011; Cummins et al., 2006; Huo et al., 2012; Koditz et al., 2007; Lee et al., 2015; Luo et al., 2011; Mikhaylova et al., 2008; Moore et al., 2015; Moser et al., 2013; Takahashi et al., 2011; Xie et al., 2012; Xie et al., 2009; Yan et al., 2011); however, as yet there is no structural or kinetic information on these, and it is possible that not all the reports of 'alternative' PHDs substrates 
will be validated. Nonetheless, given the potentially important roles of some of the substrates, it is an important issue with respect to analysis of the pharmaceutical effects of PHD inhibitors.

The PHDs and FIH belong to structurally distinct subfamilies of the 2OG dependent oxygenases (Dann et al., 2002; Elkins et al., 2003; McDonough et al., 2010). To date, pharmaceutical programmes have sought to target the PHDs specifically. Nevertheless, selective modulation of FIH (either complete or partial) may also have potential for therapeutic augmentation of the hypoxic response and deserves consideration. A number of features distinguish the two types of HIF hydroxylase. The PHDs are normally monomeric (Figure $\mathbf{3 A}$ ) and utilise the $C$-terminal region in substrate binding (Chowdhury et al., 2009; McDonough et al., 2006). In contrast, FIH is a functional dimer with oligomerisation occurring via a C-terminal helical region (Figure 3B) (Dann et al., 2002; Elkins et al., 2003; Lancaster et al., 2004). FIH is also a more 'promiscuous' enzyme, which has the capacity to hydroxylate a range of residues in addition to asparagine, in ankyrin repeat consensus within a range of ankyrin-repeat domain (ARD) containing proteins (see review (Cockman et al., 2009b)). The available FIH structures imply that the different types of HIF- $\alpha$ CAD and ARD protein substrates bind in a similarly extended manner on the FIH surface (Cockman et al., 2009a; Coleman et al., 2007; Elkins et al., 2003; Hardy et al., 2009; Wilkins et al., 2012). Notably, this binding mode must involve unfolding of the canonical ankyrin repeat fold (Cockman et al., 2009b); such unfolding is not required for the HIF- $\alpha$ CAD binding, since the CAD apparently does not have secondary structure, at least in its uncomplexed form (Dames et al., 2002; Freedman et al., 2002). The details of the ARD unfolding by FIH remain to be resolved, but knowledge of these may be useful in attempts to develop substrate selective inhibitors that selectively block ARD protein, but not HIF- $\alpha$, binding to FIH. Such compounds/inhibitors might promote FIH catalysed HIF- $\alpha$ hydroxylation and hence, HIF inactivation, by freeing up more FIH to bind to HIF- $\alpha$.

\section{HIF hydroxylase assay development}

The availability of recombinant forms of the HIF hydroxylases has enabled the development of assays for potent inhibitors (Hewitson et al., 2007b). Various assays for the HIF hydroxylases have been developed based on generic assays of 2OG oxygenase activity (for review, see (Rose et al., 2011)). 
Some of these assays employ $2 \mathrm{OG} / \mathrm{O}_{2}$ consumption and succinate/ $\mathrm{CO}_{2}$ production (Ehrismann et al., 2007; Kaule et al., 1990; McNeill et al., 2005a); however, these assays suffer from the drawback that they do not directly monitor hydroxylation, which can be problematic, since there is potential for uncoupling of $20 \mathrm{G}$ oxidation. Hence assays that directly monitor hydroxylation are preferred. Assays employing mass spectrometry (MS) and antibody based methods for the detection of hydroxylation of HIF-1 $\alpha$ fragments have been developed for both the PHDs and FIH (see e.g. (Chowdhury et al., 2013; Hewitson et al., 2007a; Lee et al., 2008; Oehme et al., 2004)), with the MS based method being preferred for directly analysing HIF- $\alpha$ hydroxylation.

Binding assay methods for the HIF hydroxylases have also been reported. These have employed protein MS (Demetriades et al., 2012; Stubbs et al., 2009) and fluorescence based assays of proximity (Cho et al., 2005; Dao et al., 2009). The monitoring of bulk water relaxation by NMR can be used to assess PHD-ligand interactions (Leung et al., 2010a). NMR-based reporter ligand displacement assays, employing $\left[{ }^{13} \mathrm{C}\right]$-labelled 2OG, have also been developed to monitor ligand binding to PHD2 and can be used to determine $K_{D}$ values and competition with $20 G$ (Leung et al., 2013).

Cell based assays for PHD inhibitors have employed antibodies to monitor HIF- $1 \alpha / 2 \alpha$ upregulation (Chan et al., 2015), as well as reporter gene assays employing fluorescence/luminescence based methods (Smirnova et al., 2010). Other cell-based assays have been derived from the measurement of changes in the expression of well-characterised HIF transcriptional targets, such as erythropoietin. One recent advance has been the development of HIF-1 $\alpha$ hydroxylation site-specific antibodies, which enable the semi-quantitative analysis of the relative efficiency of PHD and FIH catalysed HIF- $\alpha$ hydroxylations in cells (Chan et al., 2015; Lee et al., 2008; Snell et al., 2014; Tian et al., 2011). Note such assays are complicated, for instance, by the necessity for HIF- $\alpha$ levels to be unregulated in order for PHD/FIH mediated inhibition to be directly assessed. Cells that are blocked for HIF- $\alpha$ degradation, either by the application of a proteasome inhibitor, or due to the absence of functional pVHL, have been used to monitor FIH-dependent HIF-CAD hydroxylation (Tian et al., 2011). In future work, the development of PHD isoform selective inhibitors should also be aided by the availability of genetically modified cells containing an isolated single PHD isoform. 


\section{Clinically Trialed Inhibitors of the HIF hydroxylases}

To date pharmaceutical effects on HIF hydroxylase inhibition have largely focused on the catalytic domain PHDs. As discussed above, the first concerted efforts to develop human $20 \mathrm{G}$ oxygenase inhibitors came with work on the inhibition of collagen prolyl hydroxylase. The bulk of this work was carried out in pharmaceutical companies and was halted, apparently due to unanticipated effects, which may have resulted, at least in part, from inhibition of the then still to be discovered HIF prolyl hydroxylases. However, some of these relatively non-selective inhibitors, such as $\mathrm{N}$-oxalylglycine and pyridine-2,4-dicarboxylate, and prodrug forms, such as the dimethyl ester of $\mathrm{N}$-oxalylglycine (DMOG), were useful in validation of the PHDs as targets (Epstein et al., 2001; Ivan et al., 2002; Jaakkola et al., 2001; Mole et al., 2003). Early work on the selectivity of different NOG analogues for the PHD and FIH enzymes was also notable as it demonstrated that at least relatively selective inhibition of $20 \mathrm{G}$ oxygenases could be achieved by this type of molecule (McDonough et al., 2005).

The chemical structures of some of the PHD inhibitors currently in clinical trials have been revealed (Figure 4) whilst the others (such as Akebia's AKB-6548, Daiichi Sankyo's DS-1093 and Japan Tobacco's JTZ-951) remain undisclosed. Most, if not all, of the reported PHD inhibitors in pharmaceutical development, are likely to work by binding at the active site, where they have been shown, or are predicted to, complex to the ferrous iron, usually in a bidentate manner (Chan et al., 2015; Chowdhury et al., 2013; Chowdhury et al., 2009; McDonough et al., 2006; Poppe et al., 2009) and to compete with $20 G$ (Leung et al., 2013; Leung et al., 2010a). NOG competes with 20G, but (at least as shown by work on PHD2) does not displace HIF- $\alpha$ from its catalytically productive binding mode (Chowdhury et al., 2009; Epstein et al., 2001).

PHD inhibitors have now entered clinical trials for the treatment of anaemia; the first compound to be trialed was Fibrogen's FG-2216. Trials with this agent were temporarily suspended by the FDA following an adverse event (www.astellas.com/en/corporate/news/pdf/070507_eg.pdf). Although permission to resume trials was given, the company replaced clinical development of FG-2216 with the structurally related FG-4592 (www.astellas.com/en/corporate/news/pdf/080402_eg.pdf). 
Nevertheless, at least on the basis of published data, FG-2216 is one of the best studied PHD inhibitors. FG-2216 is a bicyclic isoquinoline with a glycinamide side chain as in NOG, which occupies the $20 \mathrm{G}$ binding pocket (Chowdhury et al., 2009). As revealed by crystallographic analysis FG-2216 binds to the active site metal via its glycinamide carbonyl oxygen and isoquinolyl nitrogen (Figure 4B) (Chowdhury et al., 2013; Chowdhury et al., 2009). Its phenolic hydroxyl is positioned to form an intramolecular hydrogen bond with the glycinamide NH group, which SAR work indicates is important in achieving potency (Klaus et al., 2006). The bicyclic aromatic ring system of FG-2216 slots between the side chains of hydrophobic amino acid residues which form a rather narrow (at least compared to $\mathrm{FIH}$ ) entrance to the PHD active site (Figure 5) (Chowdhury et al., 2013; Chowdhury et al., 2009). At least in vitro, FG-2216 has also been shown to inhibit other 20G oxygenases, for instance the Fat Mass and Obesity Protein, FTO (Aik et al., 2013) and ABH5 (which like FTO is an N-methyl RNA demethylase) (Aik et al., 2014). Crystallographic studies reveal FG-2216 binds to FTO in a generally similar manner to that in which binds to PHD2, though the topologies of the active sites differ substantially (Aik et al., 2013), implying that achieving selectivity should be possible, at least with respect to FTO and PHD inhibition. Interestingly, in crystallographic analysis FG-2216 is observed to undergo covalent reaction with a cysteine residue of $\mathrm{ABH} 5$, probably via nucleophilic aromatic substitution; although such reaction is likely not be important for inhibition of $20 \mathrm{G}$ oxygenases by FG-2216 in solution (Aik et al., 2014). Although analytical studies on FG-4592/Roxadustat (Fibrogen's successor to FG-2216 in clinical trials of anaemia, Figure 4D) have not yet been reported, one difference relative to FG-2216 is the presence of an additional phenoxy-group on the phenyl isoquinolyl ring, suggesting that this compound may displace HIF- $\alpha$ substrate binding more efficiently than FG-2216.

As with FG-4592, there is little reported information on the binding mode to the PHDs of the GSK's, GSK1278863 (Daprodustat, Figure 4D) which is also in clinical trials (Johnson et al., 2014). Like other PHD inhibitors, including FG-2216 and FG-4592, GSK1278863 also has a 20 G analogous glycinamide side chain; this is linked to a cyclic "tricarbonyl" motif, which is additionally functionalised to two cyclohexane rings (derived from the $N, N^{\prime}$-Dicyclohexylcarbodiimide (DCC) in the synthesis of GSK1278863) (Johnson et al., 2014; Thevis et al., 2015). The presence of the cyclohexyl rings in GSK1278863, suggests the possibility of P450 catalysed production of metabolites, which indeed have 
been observed (Johnson et al., 2014; Thevis et al., 2015); it is possible that these hydroxylated metabolites have altered inhibition properties for the PHDs or other human $20 \mathrm{G}$ oxygenases.

Bayer has developed potent tricyclic PHD inhibitors with linked pyridine-carboxylate, dihydropyrazole and triazole rings, with one compound, BAY 85-3924 (Molidustat, Figure 4D) currently in clinical trials (Flamme et al., 2014). At present there is little information about the precise mode of action of BAY 85-3924 itself; hence, we describe recent work on closely related compounds (Chan et al., 2015). These inhibitors bind to the active site iron via the nitrogen atoms of their pyridine ring and pyrazolone rings (Figure 4C). BAY 85-3924 likely binds via a related mode and notably, as with FG-2216, the NMR results of structurally related IOX4 reveal that it binds to PHD2 competitively with 20G, but that it does not substantially displace the HIF- $\alpha$ substrate (although likely alters its binding mode) (Chan et al., 2015). Importantly from a pharmaceutical perspective, the carboxylic acid side chain, which in many PHD inhibitors binds in a manner analogous to that of 20G, is replaced with an N-heterocycle in BAY 85-3924 (Meanwell, 2011).

Taken together, the available data suggests that the development of potent selective PHD inhibitors from different chemical templates is feasible (Figure 4). Whilst existing molecules act rather similarly on the PHD catalytic domains, generating new types of selective inhibitors (for instance through exploiting active site differences, differential substrate displacement or by targeting the $\mathrm{N}$-terminal regions of PHDs) should be possible. To date, drug development programmes have been directed principally towards the treatment of anaemia. Nevertheless, a substantial body of evidence points to potential benefits in a range of other conditions. This evidence encompasses data from specific genetic interventions and from pharmacological interventions that range from non-specific iron chelators and general $20 \mathrm{G}$ oxygenase inhibitors to more specific compounds developed as HIF prolyl hydroxylase inhibitors. Below, we summarise data that has been generated by the latter. For more detailed reviews of different interventions see (Bishop et al., 2015; Eltzschig et al., 2014; Koury et al., 2015; Rose et al., 2011).

\section{Therapeutic application of HIF prolyl hydroxylase inhibitors}




\section{$\underline{5.1 \quad \text { Anaemia }}$}

The extraordinary sensitivity of erythropoietin production to changes in blood oxygen availability provided the original physiological paradigm for investigations of gene regulation by hypoxia. Echoing these classical studies, augmentation of erythropoietin production has now provided the first clinical target for pharmacological inhibition of HIF prolyl hydroxylases. Relative erythropoietin deficiency is a near universal component of the anaemia associated with kidney disease. It is also a common component of anaemia associated with many other chronic diseases, particularly those involving systemic inflammation.

Although a number of organs express the erythropoietin gene at low levels, systemic production of the hormone is largely confined to the kidneys and liver, with the kidneys making much the largest contribution in adult life. Normally, erythropoietin is produced by the interstitial fibroblasts of the renal cortex (Bachmann et al., 1993; Maxwell et al., 1993a). Given that this population of cells is apparently increased in most types of kidney disease, it is not immediately clear why erythropoietin production should fail. Although altered renal tissue oxygen tension may contribute (Souma et al., 2015), the erythropoietin producing interstitial fibroblasts themselves appear to undergo rapid phenotypic changes following injury to the kidneys (Maxwell et al., 1997). These include developing a myofibroblast-like phenotype, which is associated with reduced expression of erythropoietin and reduced expression of markers such as CD73 (5' ectonucleotidase) (Maxwell et al., 1997; Souma et al., 2013). Interestingly, it has long been appreciated that erythropoietin production is not irreversibly suppressed, but can be re-activated in kidney patients by intercurrent exacerbations of anaemia or hypoxia, or even dwelling at altitude (Brookhart et al., 2008). More recently, lineage tracing studies in mouse models have established that the greatly expanded myofibroblast-like populations of cells seen in injured kidneys do indeed derive from erythropoietin-producing fibroblasts, and that erythropoietin gene expression can be reactivated by genetic inactivation of the HIF prolyl hydroxylases (Souma et al., 2015; Souma et al., 2013). Most interestingly, studies of unilateral kidney injury suggest that whilst, ordinarily, erythropoietin production by the diseased kidney is strikingly suppressed, following genetic inactivation of the PHDs it can actually exceed that of the normal kidney (Souma et al., 2015). 
Against this background, the HIF prolyl hydroxylase inhibitors described above have been developed to enhance endogenous erythropoietin production with the aim of correcting the anaemia of renal disease. Published studies of a number of HIF prolyl hydroxylase inhibitors have established the ability of these agents to promote erythropoietin production and erythropoiesis in mice, rats, non-human primates and humans (Table 1). These studies report increases in haematocrit and haemoglobin levels in normal animals, animal models of renal disease, normal humans and patients with kidney disease. Six companies; GSK, Fibrogen, Bayer, Akebia, Daiichi Sankyo and Akros Pharma, have registered clinical trials in anaemia and two have recently published the results of some of these studies. Fibrogen has recently reported on two studies (Besarab et al., 2015a; Besarab et al., 2015b). The first was a 4-week phase 2a study of FG-4592 in non-dialysis patients (CKD stage 3-4) (Besarab et al., 2015b). Patients were randomised to placebo or doses of FG-4592 ranging from $0.7 \mathrm{mg} / \mathrm{Kg}$ to $2.0 \mathrm{mg} / \mathrm{Kg}$, either $2 \mathrm{x}$ or $3 \mathrm{x}$ weekly. Proportions of patients reaching the target increase in haemoglobin of $1 \mathrm{~g} / \mathrm{dl}$ ranged from $30 \%$ for $0.7 \mathrm{mg} / \mathrm{Kg} 2 \mathrm{x}$ weekly, to $100 \%$ for either $2.0 \mathrm{mg} / \mathrm{Kg}$ regimen. The second Fibrogen publication reported a 12-week open label study of FG-4592 in dialysis patients, in which patients were treated with FG-4592 up to a maximum of $2.5 \mathrm{mg} / \mathrm{kg} 3 x$ weekly. Almost all (96\%) of patients reached their target (rise in haemoglobin $>1 \mathrm{~g} / \mathrm{dl}$ ) and the mean change in haemoglobin from baseline was $3.1 \mathrm{~g} / \mathrm{dl}$ over 12 weeks (Besarab et al., 2015a). GSK reported a 4-week phase 2a study in both dialysis patients and non-dialysis patients with CKD stage 3-5 (Holdstock et al., 2015). Non-dialysis patients had not previously received rhEPO (recombinant human Epo) and were randomised to placebo or GSK1278863 at total doses of $0.5 \mathrm{mg}, 2 \mathrm{mg}$ or $5 \mathrm{mg}$ once per day, whilst dialysis patients were randomised to continue rhEPO or receive the same doses of GSK1278863. The study established that the $5 \mathrm{mg}$, but not the lower doses, was effective in raising haemoglobin by a mean of $1 \mathrm{~g} / \mathrm{dl}$ or maintaining haemoglobin levels in dialysis patients withdrawn from rhEPO. None of these studies reported an excess of adverse events in treatment groups.

Given the uncertainties involved in systemic activation of the hypoxia response, it is important to consider the potential advantages of HIF prolyl hydroxylase inhibitors, beyond the simple expedient of an oral route of delivery. Firstly, an increased incidence of cardiovascular events has been observed in several trials in which patients were being treated with higher doses of rhEPO to achieve a high 
target haematocrit (Besarab et al., 1998; Unger et al., 2010). Though the mechanisms underlying these adverse events are not well understood, secondary analyses of these trials suggest that it was the high doses of rhEPO rather than high haemoglobin that was associated with risk (Szczech et al., 2008), and it has been proposed that very high levels of plasma erythropoietin have vascular toxicity (McCullough et al., 2013). Although HIF prolyl hydroxylase inhibitors have the potential to generate high plasma erythropoietin levels, several studies of these drugs in animals and humans have demonstrated that target haemoglobin levels can be achieved with more modest rises in plasma erythropoietin that are within the physiological range (Barrett et al., 2011; Barrett et al., 2015; Besarab et al., 2015b; Flamme et al., 2014; Holdstock et al., 2015; Hsieh et al., 2007), and hence might be predicted to avoid this risk.

Systemic activation of the HIF pathway by HIF prolyl hydroxylase inhibitors may also have actions on erythropoiesis that augment the effects of erythropoietin. Although erythropoietin is absolutely necessary for erythropoiesis, clinical and experimental observations suggest that HIF hydroxylase pathways may have additional direct actions on the bone marrow. For instance, erythroid colonies derived from patients with Chuvash polycythaemia, in which systemic activation of the HIF system is generated by a hypomorphic von Hippel Lindau protein allele, manifest hypersensitivity to erythropoietin (Ang et al., 2002), whilst similar findings have been reported, following genetic inactivation of PHD2, in mice (Arsenault et al., 2013). Although multiple HIF target genes have been defined in haematopoietic tissues, the exact target cells and molecular processes underlying these observations are unclear.

HIF also targets molecules involved in multiple steps in iron absorption, metabolism and transport (for review see (Haase, 2013; Shah et al., 2014)) so that activation of the system by HIF prolyl hydroxylase inhibitors has the potential to enhance iron availability for erythropoiesis. Nevertheless, the complexity and wide tissue distribution of relevant actions makes overall effects difficult to predict, particularly since enhanced erythropoiesis itself activates iron transport processes. For instance, reduction in hepcidin is observed in patients treated with HIF prolyl hydroxylase inhibitors (Besarab et al., 2015a; Besarab et al., 2015b; Holdstock et al., 2015), but it is unclear whether this is a direct effect of HIF, an indirect of HIF or a simple consequence of stimulating erythropoiesis. Studies to date 
have reported that biomarkers of iron balance remain largely unchanged in patients treated with HIF prolyl hydroxylase inhibitors without adjustments to iron supplementation. In Fibrogen's study of FG4592 in dialysis patients, subjects were assigned to different iron supplementation regimens (no iron, oral iron or iv iron) (Besarab et al., 2015a). Changes in indices of iron balance and a somewhat reduced haemoglobin rise in the no iron group indicated a need for some form of iron supplementation, but were not different in the oral and iv supplementation groups. This strongly suggests an improvement over historical findings on iron-limited erythropoiesis in patients receiving rhEPO (Macdougall et al., 1996). However there are no published studies of iron absorption in patients given HIF prolyl hydroxylase inhibitors or direct comparisons with the effects of rhEPO. Interestingly however, one experimental study in rats in which JNJ-42905343 was given orally demonstrated a marked induction of the HIF target genes DMT1 and DCtyB, which mediate iron absorption in the duodenal epithelium (Barrett et al., 2015). Such effects, which would likely occur independently of systemic absorption, raise the possibility that pharmacokinetic properties may be important in defining effects on iron absorption.

Another possibility is that specific groups of patients may respond better to HIF prolyl hydroxylase inhibitors than rhEPO. Systemic inflammation substantially reduces the responsiveness of patients to rhEPO (Drüeke, 2001) and it is also reported to reduce the responses of erythropoietin-producing cells to hypoxic stimulation (Jelkmann, 2011; Souma et al., 2013). Interestingly however, recent publications report that HIF prolyl hydroxylase inhibitors (BAY 85-3934, JNJ-42041935 and JNJ42905343) were effective in the correction of haematocrit in a rat model of inflammatory arthritisassociated anaemia generated by intra-peritoneal injection of peptidoglycan-polysaccharide (PGPS) (Barrett et al., 2011; Barrett et al., 2015; Flamme et al., 2014). The study from Janssen demonstrated that whereas JNJ-42905343 at a dose $(3 \mathrm{mg} / \mathrm{kg})$ that raised haemoglobin effectively in normal rats, corrected anaemia in the PGPS model, rhEPO at a dose (50ug/Kg/week), which was only slightly less effective than JNJ-42905343 in normal rats, had no effect in the PGPS model (Barrett et al., 2015). These observations are similar to an earlier study conducted in the same anaemia model using JNJ42041935 (Barrett et al., 2011). Neither study revealed major effects of HIF hydroxylase inhibition on markers of inflammation, but all three studies revealed strong stimulation of erythropoietin 
production. The Janssen study also reported on markedly more erythroid appearances in the bone marrow, but it was not clear whether this arose as a consequence of erythropoietin stimulation, or implied some additional action. Interestingly, in the study of FG-4592 in dialysis patients, it was reported that rises in haemoglobin were independent of plasma levels of the inflammatory marker Creactive protein (Besarab et al., 2015a).

Experimental studies on myofibroblast-like populations derived from the renal erythropoietin producing cells indicate that some types of renal disease that are associated with expansion of this population might show enhanced responses to HIF prolyl hydroxylase inhibitors. One study reporting individual responses in nephric and anephric patients reported strikingly variable responses of plasma erythropoietin amongst nephric haemodialysis patients, some of which exceeded those in normal subjects (Bernhardt et al., 2010). Details of individual erythropoietin responses were not reported in the three recent phase 2 studies (Besarab et al., 2015a; Besarab et al., 2015b; Holdstock et al., 2015). However, the report on GSK1278863 gave a very wide range in erythropoietin response for the dialysis patient group given the highest dose of the study drug, and commented on inter-subject variability (Holdstock et al., 2015). In the report on pre-dialysis patients given FG-4592, a number of patients experienced excessive rises in haemoglobin and planned higher treatment doses were withdrawn, again suggesting that some responses were unexpectedly strong (Besarab et al., 2015b).

Overall, the most important uncertainties relate to whether HIF prolyl hydroxylase inhibitor dosing schedules can deliver sufficient selectivity on erythropoietin to avoid the general effects of HIF activation, and/or whether the risk to benefit balance of doing so is favourable. So far studies have been limited. In the phase 2a clinical study, GSK1278863 was not associated with statistically significant increases in plasma VEGF levels, although it was reported that these were very variable (Holdstock et al., 2015). Limited studies of gene expression in animals have reported relatively selective increases in erythropoietin mRNA in the liver and kidneys. For instance, in the kidneys of rats given BAY 85-3934, increases in erythropoietin mRNA greatly exceeded increases in a panel of other HIF target genes (Flamme et al., 2014). Interestingly, this study also reported a large reduction in blood 
pressure in response to BAY 85-3934 in a subtotal nephrectomy model of renal failure in the rat, but not in normal animals (Flamme et al., 2014).

\section{$\underline{5.2 \quad \text { Ischaemia }}$}

Organ ischaemia (inadequate blood flow) is a major clinical problem, arising principally from cardiovascular and circulatory diseases, but also sometimes during surgery that requires circulatory interruption or diversion. All organs may be affected, but common sites include the brain (as in stroke), the heart, the kidneys and the limbs. Ischaemia may be acute (where blood is suddenly reduced over minutes or hours) or chronic (where blood flow is progressively reduced over weeks or years). Tissue hypoxia is a near universal feature of ischaemia, but is complicated by reduced delivery and clearance of metabolites. In keeping with this, the HIF system is induced to a variable extent in ischaemic tissues (Rosenberger et al., 2002; Willam et al., 2006). The principal underlying use of HIF prolyl hydroxylase inhibitors in these settings is that augmentation of HIF activity may enhance the endogenous protective or reparative responses. Potentially such an approach could address a massive unmet medical need.

A very large number of genetic and pharmacological studies have sought to address whether activation of HIF can improve the outcome of experimental ischaemia in a range of animal models ((Aragones et al., 2008; Holscher et al., 2011; Hyvarinen et al., 2010; Takeda et al., 2011) and reviewed in (Bishop and Ratcliffe, 2015; Eltzschig et al., 2014; Eltzschig et al., 2011b; Fraisl et al., 2009)). The large majority, though not all, of these have delivered a positive outcome at least in the short-term. Table 2 summarises the data on rat or mouse models of brain, heart and kidney ischaemia using agents that are closely related or identical to those which have been used in clinical trials for anaemia. In models of brain ischaemia, treatments either shortly before, or almost immediately after, arterial occlusion improved outcome as assessed by infarct volume (Chen et al., 2014; Reischl et al., 2014; Siddiq et al., 2005). In the heart, studies of coronary ligation have revealed benefit from HIF prolyl hydroxylase inhibition both through reduction in infarct size and (when treatment has been applied post-ischaemically) in improved ventricular function (Bao et al., 2010; Ong et al., 2014; Philipp et al., 2006; Vogler et al., 2015). Nevertheless, these benefits need to be set against potential detrimental 
effects on cardiac function (cardiomyopathy) that have been observed with long-term genetic inactivation of PHD2 (Minamishima et al., 2008), and which appear to be enhanced by concurrent inactivation of multiple PHD isoforms (Minamishima et al., 2009). In the kidney, studies of transient renal artery occlusion have observed that pre- but not post-ischaemic treatment resulted in improved function and histological outcome (Bernhardt et al., 2006; Kapitsinou et al., 2012; Rosenberger et al., 2008; Wang et al., 2012). Most interestingly, in a rat model of renal allo-transplantation, a single intravenous injection of FG-4497 to the donor animals was found to improve both early and late graft survival (Bernhardt et al., 2009). The outcome of organ transplantation involves a complex interplay between ischaemia and immune/inflammatory pathways, so that the mechanisms underlying such an effect are particularly difficult to define. Nevertheless, the study demonstrates the potential for benefit from PHD inhibition in an important clinical setting.

Overall, a very large number of ischaemia-protective mechanisms have been ascribed to specific HIF pathways or target genes. Some, such as reprogramming of cellular metabolism, effects on apoptotic/survival pathways, or altered vascular permeability could potentially act very rapidly. Others, for instance angiogenesis and revascularisation, tissue repair, stem cell activation and homing, matrix remodelling, are likely to operate over a longer time-scale. However, it remains largely unclear which of these mechanisms mediate the observed effects in the different models of ischaemia.

Although a few studies have compared treatments with HIF prolyl hydroxylase inhibitors pre- and post-ischaemia, the time window for effective therapeutic intervention remains poorly understood. This is an important gap in knowledge. In clinical practice, applying interventions prior to ischaemia is extremely difficult outside planned surgical procedures. Even very early intervention after acute ischaemia can pose logistical problems and often would require the new therapy to be trialled on top of complex interventions that form current standards of care. These considerations may account, at least in part, for the notoriously poor translation of findings from experimental models of ischaemia into clinical practice, and hence for the paucity of registered clinical trials of HIF prolyl hydroxylase inhibitors in ischaemia, in comparison with anaemia. 
Because the HIF system is capable of augmenting anti-ischaemia responses such as neovascularisation, which likely operate over long periods of time, another clinical scenario which deserves consideration is chronic ischaemia. Many patients suffer from intractable myocardial or limb ischaemia, despite medical and surgical treatment, and might benefit from HIF prolyl hydroxylase inhibitors. In this setting, it would be important to avoid excessive erythropoiesis, but this might be limited by intermittent treatment regimens or the use of agents that were less concentrated in the erythropoietin producing tissues. Alternatively some patient groups suffer concurrent anaemia where erythropoietic effects would be desirable. For instance, diabetic kidney disease is frequently complicated by severe vascular disease and such patients might be particularly suitable for treatment.

Unfortunately, at present there is a mismatch between the focus of experimental studies on shortterm outcome following acute ischaemia and the likely focus of clinical application. It would be useful to understand the duration of treatment required to improve chronic ischaemia and the duration of any effect after treatment withdrawal. To date the only reported study of clinical ischaemia is a single dose and a 14-day trial of GSK1278863 in patients suffering from chronic limb ischaemia (Olson et al., 2014). No improvement in symptoms or walking distance was observed and no increase in HIF target gene expression was observed in muscle biopsies. However, this does not exclude benefit from longer or more intense treatment or that changes would have been observed by more detailed study.

\section{$\underline{5.3 \quad \text { Inflammation }}$}

Inflammation is a central component of many human diseases, driven by multiple factors, including responses to pathogens, tissue injury, and dysregulated immunity. HIF is commonly activated in inflamed tissues both by hypoxia within the inflammatory cell mass and by non-hypoxic signals which activate HIF pathways at multiple levels (Eltzschig et al., 2014; Eltzschig and Carmeliet, 2011a; Nizet and Johnson, 2009). Activated HIF has multiple effects on immune and inflammatory cells, including effects on differentiation, apoptosis and cytokine production (Eltzschig et al., 2014; Eltzschig and Carmeliet, 2011a; Nizet and Johnson, 2009). Apparently conflicting responses have been described in some cell types. For instance, in different contexts induction of HIF-1 has been reported to activate pro-inflammatory Th17 T-cells by up-regulation and co-activation of the transcription factor ROR-gt 
(Dang et al., 2011) and to activate anti-inflammatory suppressor T-cells by transactivation of FoxP3 (Clambey et al., 2012). Other studies have described potentially opposing isoform effects of activating HIF-1 versus HIF-2. For instance, macrophage activation can be polarised to an M1 (pro-inflammatory) phenotype by HIF-1 $\alpha$ or an M2 (anti-inflammatory) phenotype by HIF-2 $\alpha$ (Takeda et al., 2010). Actions of HIF in inflamed tissues are further complicated by diverse activities on non-inflammatory cells. For instance, HIF activation can promote either enhanced barrier function (Furuta et al., 2001) or epithelial-to-mesenchyme transition (Higgins et al., 2007), under different circumstances. The HIF pathway also appears to be subverted for cell entry, replication or survival by a range of pathogens (Deshmane et al., 2011; Kempf et al., 2005; Morinet et al., 2013; Singh et al., 2012). Despite these complexities, activation of HIF has been reported to improve outcome in a range of inflammatory models. Studies using HIF prolyl hydroxylase inhibitors that are closely related or identical to those in clinical development are summarised in Table 3; for more general review see (Eltzschig et al., 2014).

In a mouse model of ulcerative colitis generated by the administration of trinitrobenezene sulphonic acid, FG-4497 and AKB-4924 conferred therapeutic benefit as judged by the reduction of weight loss, colon shortening and histological damage (Keely et al., 2014; Marks et al., 2015; Robinson et al., 2008). Mechanisms of protections were proposed to include a HIF-1-mediated improvement in epithelial barrier function and healing, as well as a decrease in the inflammatory response. In another study, of acute lung injury in the mouse, FG-4497 was associated with reduction in leukocyte infiltration and increased survival rate (Gong et al., 2015). In this case, the mechanism of protection in this study was proposed to be via HIF2-dependent induction of vascular endothelial protein tyrosine phosphatase (VE-PTP), leading to an increase in vascular barrier integrity in the lung. Other studies have examined the effect of HIF prolyl hydroxylase inhibitors in the inflammation associated with bacterial infection. For instance, in mice bearing Staphylococcus aureus skin abscesses AKB-4924 administration resulted in a decrease in lesion size (Okumura et al., 2012). Subsequent study of this inhibitor in another skin infection model (LPS-induced inflammation) proposed a HIF-1-dependent mechanism of enhanced neutrophil recruitment by keratinocytes (Leire et al., 2013). In a mouse model of urinary-tract infection (UTI), AKB-4924 administration directly to the bladder reduced both inflammation and bacterial burden in the kidney caused by uropathogenic Eschericia coli (Lin et al., 2015). Another study 
reported that GSK360A mitigated the increase in blood lactate level and increased the survival rate in an endotoxin shock mouse model; a mechanism proposed to be mediated via inhibition of the hepatic Cori cycle (Suhara et al., 2015).

\section{Summary}

The available data suggests that current generation HIF prolyl hydroxylase inhibitors are effective in the correction of anaemia associated with erythropoietin deficiency and well tolerated, at least under the conditions studied. For the treatment of anaemia, determination of long-term safety, and efficacy equivalent or superior to rhEPO, is now a key challenge. From the medical perspective, a central question is whether therapy can be applied in a way that largely restricts actions to the stimulation of erythropoietin or, if not, whether and under what circumstances the additional 'extra-erythropoietin' actions are beneficial or adverse.

If effectively 'erythropoietin-restricted' action is feasible, then a logical initial clinical strategy would be to deploy agents that are most effectively concentrated in the erythropoietin producing organs (kidneys and liver) and to use them at the lowest effective dose. An important question is whether large-scale trials could initially be focused on, or enriched for, those patients who are poor responders to rhEPO or (should evidence for heterogeneity in response to HIF prolyl hydroxylase be substantiated) to those who respond particularly well to these agents. Of particular interest in this respect is the apparent efficacy of HIF prolyl hydroxylase inhibitors in the face of markers of systemic inflammation.

If it is not possible to generate sufficient selectively with respect to the erythropoietin response, then clearly there is a need to define and optimise the risk-benefit ratio of actions on other components of the HIF hydroxylase pathways. Potential anti-ischaemic and anti-inflammatory actions have been discussed above, as have potentially beneficial actions on iron balance and haematopoietic precursors in the marrow. Careful experimental and clinical assessment is required to assess, and, if possible, optimise these effects. Equally, possible adverse effects, such as cardiomyopathy, pulmonary vasoconstriction, retinal neo-vascularisation, and pro-inflammatory effects, need to be assessed and avoided. This complexity creates a problem in defining priorities. 
Since in many groups of renal patients there is a high incidence of cardiovascular disease, and high dose rhEPO has been associated with increased cardiovascular risk, a critical question is whether HIF prolyl hydroxylase inhibitors have clinically useful benefits on cardiovascular disease in this setting. Defining as accurately as possible, from experimental animal and early phase clinical studies, the time windows under which beneficial effects can be observed on the most clinically relevant parameters will be important. Unfortunately, to date, experimental studies have largely been confined to assessment of short-term improvement under dosing conditions that will be difficult to translate into clinical practice. In the future, it will be important to define the dose/time windows necessary to generate improved vascular flow in diseased vessels and/or sustained functional improvement in ischaemic tissues. Also important in guiding definitive clinical studies will be the careful assessment of effects on known cardiovascular risk factors, such as blood pressure, lipid and glucose homeostasis.

In parallel with defining strategies for treatment of anaemia, an important consideration is whether HIF prolyl hydroxylase inhibitors could be used in hypoxic disease settings that are not associated with anaemia. Acute and chronic ischaemia of different organs represents an enormous area of unmet medical need. However, it is an area with a particularly poor record for the translation of experimental findings into clinical practice. As outlined above, we would argue for greater investment in defining the dosage and time windows required to generate clinically useful signals of efficacy. This is particularly the case as it will likely be necessary to define dosing schedules that avoid excessive erythrocytosis. Similar considerations apply to the use of HIF hydroxylase inhibitors in inflammatory conditions. Here an important consideration is whether agents can effectively be formulated for nonsystemic use. Experimental studies have suggested benefit in gastro-intestinal (colitis) and skin conditions (chronic ulceration, wound healing (Botusan et al., 2008; Kalucka et al., 2013; Wetterau et al., 2011; Zimmermann et al., 2014)) that might respond to the local application of HIF hydroxylase inhibitors. Indeed, GSK is currently recruiting participants in a Phase 1 clinical trial of topical GSK1278863 administration as treatment for wound healing in subjects with diabetic foot ulcers (https://clinicaltrials.gov/ct2/show/NCT01831804?term=1278863\&rank=17). 
From the chemical and pharmacological perspective, these considerations argue strongly for the development and careful testing (e.g. variations in dosing regimes/delivery methods) of multiple PHD inhibitors with different profiles, including with respect to PHD/HIF isoform selectivity and pharmacodynamic properties. As argued above, it is likely that the molecules that are most concentrated in the kidneys and liver would likely be the most appropriate in treating anaemia. Equally, if non-erythropoietic effects are desired, then agents that are the least concentrated in the kidneys and liver or preferentially targeted to other organs are likely to be the most appropriate. Defining non-invasive pharmacodynamic measures that could be applied clinically (e.g. assessment of metabolic actions in different organs, including the brain, by PET scanning, or MR assessments of perfusion) would be useful in defining whether existing dosing schedules were indeed affecting the desired target organs.

Structural and kinetic considerations, together with evidence for differential effects on HIF- $\alpha$ substrate displacement amongst existing inhibitors, indicate that chemical differentiation should be possible. Though overall domain structure is conserved, degradation of HIF-1 $\alpha$ and HIF- $2 \alpha$ appears to be differentially dependent on NODD and CODD sites of prolyl hydroxylation and on the activity of different PHDs. Since these HIF- $\alpha$ isoforms have apparently opposing effects on some responses to hypoxia, even modest specificity amongst HIF prolyl hydroxylase inhibitors might generate clinically useful differentiation. On the other hand, the continuing activity of FIH will modulate the expression of specific sets of HIF target genes in cells exposed to HIF prolyl hydroxylase inhibitors (Dayan et al., 2009; Dayan et al., 2006). Therefore, the design of inhibitors that combine activity against the two types of HIF hydroxylases may be useful in some circumstances.

To support this translational work, relevant areas of basic biology require further investigation. In considering the design of substrate selective inhibitors, the biological significance of the very large number of non-HIF substrates that have been reported for the HIF prolyl hydroxylases requires urgent clarification. On the other hand, a better understanding of whether, and under what circumstances, other $20 \mathrm{O}$ oxygenase activities contribute to the regulation of specific components of the HIF pathway would be helpful in assessing the utility of inhibitors with broader activity profiles. Given evidence of 
the binding of existing HIF prolyl hydroxylase inhibitors to a number of other $20 \mathrm{G}$ oxygenases, more extensive profiling of inhibitors against $20 \mathrm{G}$ oxygenases will be important.

In our view these considerations argue strongly for complementing current translational efforts with attempts to design and test chemically diverse inhibitors in the most clinically relevant models, and in small-scale human studies, in order to define the therapeutic potential of this new area of medicine as fully as possible.

\section{Figure legends}

Figure 1:

Schematic diagram illustrating the oxygen dependent regulation of HIF- $\alpha$ by the PHDs and FIH. Possible interventions to activate (blue boxes) or to inactivate (orange boxes) the HIF pathway are indicated.

Figure 2:

Outline of the catalytic mechanism for PHDs and FIH showing possible modes of inhibition for PHD and FIH.

Figure 3: The PHDs and FIH belong to different structural subfamilies of 2-oxglutarate dioxygenases.

A) View from a crystal structure of the catalytic domains of PHD2, highlighting the flexible $\beta 2 \beta 3$ loop and the HIF- $1 \alpha$ CODD substrate relative to the 20 G/NOG binding site (left panel). Note the $\beta 2 \beta 3$ loop folds to enclose the substrate at the active site. View of the PHD2 active site, highlighting the metal coordination by His313, Asp315, His374 and NOG, as well as the electrostatic interaction between the C-5 carboxylate of NOG (a 20 isostere) and Arg383 (middle panel). The HIF-1 $\alpha$ prolyl hydroxylation reaction as catalysed by the PHDs (right panel).

B) View from a crystal structure of the FIH dimer, highlighting the HIF-1 $\alpha$ CAD substrate relative to the $20 \mathrm{G}$ binding site (left panel). View of the FIH active site, highlighting metal coordination by His279, His199, Asp201 and 20G, as well as interaction between the 20G and C-5 carboxylate with a lysine 
(Lys214) rather than an arginine, as in PHD2 (middle panel). The HIF-1 $\alpha$ asparaginyl hydroxylation reaction as catalysed by FIH (right panel).

Figure 4: PHD inhibitor binding modes

Views of N-oxalylglycine (NOG) (A), FG-2216 (B) and on IOX4 analogue (IOX4 is identical except for the presence of a t-butyl ester rather than an acid (C) binding modes to the active site of PHD2. (D) Chemical structures of PHD inhibitors in clinical and/or pre-clinical studies; structural similarities to the inhibitors with binding information highlighted in colour.

Figure 5: Entrances to the active site of PHD2 and FIH.

Surface representation from crystal structures of FIH in complex with N-oxalyl-D-phenylalamine (left) and PHD2 in complex with FG-2216 (right), comparing the entrances to the active site cavities.

\section{Acknowledgements}

The work in the authors' laboratories was supported by the Wellcome Trust, the Biotechnology and Biological Sciences Research Council, Cancer Research UK, the British Heart Foundation and the Ludwig Institute for Cancer Research.

\section{Disclosure statement}

PJR and CJS are scientific co-founders and hold equity in ReOx Ltd., a University spin-out company that seeks to develop therapeutic inhibitors of HIF hydroxylases. 
HIF hydroxylase inhibitors in pre-clinical and clinical studies

Table 1: Anaemia

\begin{tabular}{|c|c|c|c|c|c|}
\hline Inhibitor & Disease model & Species & $\begin{array}{l}\text { Route of } \\
\text { administration }\end{array}$ & Outcome & References \\
\hline \multicolumn{6}{|c|}{ PRE-CLINICAL STUDIES } \\
\hline \multirow[t]{3}{*}{$\begin{array}{l}\text { BAY 85-3934 } \\
\text { (Molidustat) }\end{array}$} & Normal & Rat & Oral & $\begin{array}{l}\text { Increased plasma EPO, } \\
\text { proportion of reticulocytes } \\
\text { and EPO mRNA (in the } \\
\text { kidney) with single dose. } \\
\text { Increased haematocrit with } \\
\text { repeat doses (once daily) } \\
\text { over } 26 \text {-day period. }\end{array}$ & $\begin{array}{l}\text { (Flamme et } \\
\text { al., 2014) }\end{array}$ \\
\hline & Normal & $\begin{array}{l}\text { Cynomolgus } \\
\text { monkey }\end{array}$ & Oral & $\begin{array}{l}\text { Increased plasma EPO with } \\
\text { single dose. } \\
\text { Increased haemoglobin, red } \\
\text { blood cell counts and } \\
\text { reticulocytes with repeat } \\
\text { doses (once daily) over a } \\
\text { 28-day period. }\end{array}$ & \\
\hline & $\begin{array}{l}\text { Gentamicin- } \\
\text { induced renal } \\
\text { anaemia }\end{array}$ & Rat & Oral & $\begin{array}{l}\text { Increased plasma EPO and } \\
\text { EPO mRNA (in the kidney } \\
\text { and liver) with single dose. } \\
\text { Prevented decline in } \\
\text { haematocrit (over >35-day } \\
\text { period) and corrected } \\
\text { decrease in haemoglobin } \\
\text { (after 7-day period) in this } \\
\text { anaemia model with repeat } \\
\text { doses ( } 5 \text { doses a week). }\end{array}$ & \\
\hline
\end{tabular}




\begin{tabular}{|c|c|c|c|c|c|}
\hline & $\begin{array}{l}\text { PGPS-induced } \\
\text { inflammatory } \\
\text { anaemia }\end{array}$ & Rat & Oral & $\begin{array}{l}\text { Reversed decline in } \\
\text { haematocrit and increased } \\
\text { in EPO mRNA (in the } \\
\text { kidney) with repeat doses } \\
\text { (once daily) over a 5-week } \\
\text { period. } \\
\text { Decreased mRNA levels of } \\
\text { hepcidin and monocyte } \\
\text { chemotaxic-protein-1. }\end{array}$ & \\
\hline \multirow[t]{2}{*}{ FG-2216 } & Normal & Mouse & Intravenous & $\begin{array}{l}\text { Increased plasma EPO } \\
\text { with single dose. }\end{array}$ & $\begin{array}{l}\text { (Hsieh et al., } \\
\text { 2007) }\end{array}$ \\
\hline & Normal & $\begin{array}{l}\text { Rhesus } \\
\text { macques }\end{array}$ & Oral & $\begin{array}{l}\text { Increased plasma EPO with } \\
\text { single dose. } \\
\text { Increased proportion of } \\
\text { reticulocytes and HbF- } \\
\text { containing reticulocytes } \\
\text { with repeat doses (twice } \\
\text { weekly) over a 2-week } \\
\text { period. }\end{array}$ & \\
\hline FG-4497 & Normal & Mouse & $\begin{array}{l}\text { Oral } \\
\text { and } \\
\text { intravenous }\end{array}$ & $\begin{array}{l}\text { Increased plasma EPO with } \\
\text { single dose. } \\
\text { Increased haemoglobin and } \\
\text { haematocrit with repeat } \\
\text { doses ( } 3 \text { doses) over 7-day } \\
\text { period. }\end{array}$ & $\begin{array}{l}\text { (Robinson et } \\
\text { al., 2008) }\end{array}$ \\
\hline \multirow[t]{2}{*}{$\begin{array}{l}\text { JNJ- } \\
42041935\end{array}$} & Normal & Mouse & Oral & $\begin{array}{l}\text { Increased plasma EPO with } \\
\text { single dose. } \\
\text { Increased proportion of } \\
\text { reticulocytes, haemoglobin } \\
\text { and haematocrit after } \\
\text { repeat doses over a 5-day } \\
\text { period (once daily). }\end{array}$ & $\begin{array}{l}\text { (Barrett et al., } \\
\text { 2011) }\end{array}$ \\
\hline & $\begin{array}{l}\text { PGPS-induced } \\
\text { inflammatory } \\
\text { anaemia }\end{array}$ & Rat & Oral & $\begin{array}{l}\text { Increased reticulocytes, red } \\
\text { blood cell count, } \\
\text { haemoglobin, haematocrit, } \\
\text { MCV and MCH with repeat } \\
\text { doses (once daily) over a } \\
\text { 14-day period. }\end{array}$ & \\
\hline
\end{tabular}




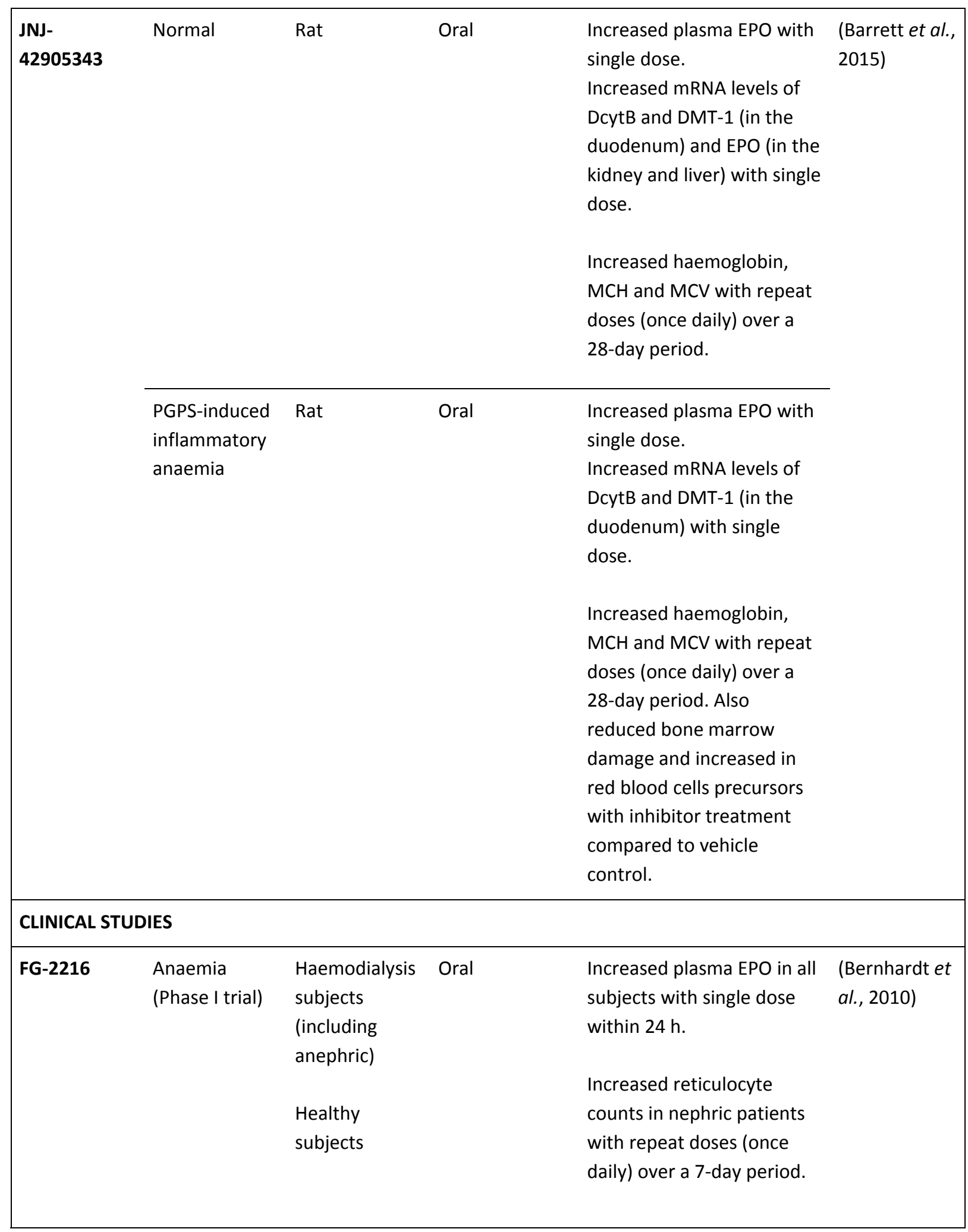




\begin{tabular}{|c|c|c|c|c|c|}
\hline \multirow[t]{2}{*}{ FG-4592 } & $\begin{array}{l}\text { Anaemia } \\
\text { (Phase 2a trial) }\end{array}$ & $\begin{array}{l}\text { Anaemic non- } \\
\text { dialysis- } \\
\text { dependent } \\
\text { CKD subjects }\end{array}$ & Oral & $\begin{array}{l}\text { Increased haemoglobin } \\
\text { levels and plasma EPO, and } \\
\text { reduced serum hepcidin } \\
\text { levels in inhibitor-treated } \\
\text { subjects with } 2 x \text { weekly or } \\
3 x \text { weekly doses over a } 4- \\
\text { week period. }\end{array}$ & $\begin{array}{l}\text { (Besarab et } \\
\text { al., 2015b) }\end{array}$ \\
\hline & $\begin{array}{l}\text { Anaemia } \\
\text { (Phase } 2 \mathrm{~b} \\
\text { trial) }\end{array}$ & $\begin{array}{l}\text { Haemodialysis } \\
\text { or peritoneal } \\
\text { dialysis CKD } \\
\text { subjects with } \\
\text { or without } \\
\text { iron } \\
\text { supplements }\end{array}$ & Oral & $\begin{array}{l}\text { Increased haemoglobin } \\
\text { levels and reduced serum } \\
\text { hepcidin levels, with } 3 x \\
\text { weekly doses over a 12- } \\
\text { week period. }\end{array}$ & $\begin{array}{l}\text { (Besarab et } \\
\text { al., 2015a) }\end{array}$ \\
\hline GSK1278863 & $\begin{array}{l}\text { Anaemia } \\
\text { (Phase 2a trial) }\end{array}$ & $\begin{array}{l}\text { Haemodialysis } \\
\text { and non- } \\
\text { dialysis CKD } \\
\text { subjects }\end{array}$ & Oral & $\begin{array}{l}\text { Increased in haemoglobin } \\
\text { and plasma EPO levels in } \\
\text { non-dialysis subjects with } \\
\text { once daily dose over a 4- } \\
\text { week period. Also } \\
\text { decreased hepcidin levels. } \\
\text { Maintained haemoglobin } \\
\text { levels after switching from } \\
\text { rhEPO in haemodialysis } \\
\text { subjects with once daily } \\
\text { dose over a 4-week period. } \\
\text { Also increased in EPO levels } \\
\text { and no change in hepcidin } \\
\text { levels from baseline. }\end{array}$ & $\begin{array}{l}\text { (Holdstock et } \\
\text { al., 2015) }\end{array}$ \\
\hline
\end{tabular}

rhEPO: recombinant human EPO; PGPS: Peptidoglycan-polysaccharide; MCV: mean corpuscular volume; $\mathrm{MCH}$ : mean corpuscular haemoglobin. DcytB: duodenum cytochrome B; DMT-1: divalent metal transporter-1, CKD: chronic kidney disease FG-2216 is also known as IOX3. 
Table 2: Ischaemia

\begin{tabular}{|c|c|c|c|c|c|}
\hline Inhibitor & Disease model & Species & $\begin{array}{l}\text { Route of } \\
\text { administration }\end{array}$ & Outcome & References \\
\hline \multicolumn{6}{|c|}{$\begin{array}{l}\text { PRE-CLINICAL STUDIES } \\
\text { Brain }\end{array}$} \\
\hline Compound A & $\begin{array}{l}\text { Permanent } \\
\text { cerebral } \\
\text { ischaemia }\end{array}$ & Rat & Oral & $\begin{array}{l}\text { Reduced brain infarct size } \\
\text { with treatment at } 6 \mathrm{~h} \text { before a } \\
\text { permanent MCAO. }\end{array}$ & $\begin{array}{l}\text { (Siddiq et al., } \\
\text { 2005) }\end{array}$ \\
\hline FG-2216 & $\begin{array}{l}\text { Transient } \\
\text { cerebral } \\
\text { ischaemia }\end{array}$ & Mouse & Intravenous & $\begin{array}{l}\text { Reduced brain infarct size } \\
\text { with treatment at } 24 \mathrm{~h} \text { before } \\
\text { transient MCAO. }\end{array}$ & $\begin{array}{l}\text { (Chen et al., } \\
\text { 2014) }\end{array}$ \\
\hline FG-4497 & $\begin{array}{l}\text { Permanent and } \\
\text { transient } \\
\text { cerebral } \\
\text { ischaemia }\end{array}$ & Mouse & Intraperitonial & $\begin{array}{l}\text { Reduced brain infarct size and } \\
\text { decreased formation of } \\
\text { vasogenic oedema with } \\
\text { treatment at } 6 \mathrm{~h} \text { before } \\
\text { transient MCAO. } \\
\text { Reduced brain infarct size } \\
\text { with treatment at } 1 \mathrm{~h} \text { after } \\
\text { permanent MCAO. }\end{array}$ & $\begin{array}{l}\text { (Reischl et al., } \\
\text { 2014) }\end{array}$ \\
\hline \multicolumn{6}{|l|}{ Heart } \\
\hline \multirow[t]{2}{*}{ FG-2216 } & $\begin{array}{l}\text { Myocardial } \\
\text { infarction }\end{array}$ & Rat & Oral & $\begin{array}{l}\text { Improved cardiac function } \\
\text { (without effect on infarct size) } \\
\text { with treatment over a 9-day } \\
\text { period starting at } 48 \mathrm{~h} \text { prior to } \\
\text { LAD ligation. }\end{array}$ & $\begin{array}{l}\text { (Philipp et al., } \\
\text { 2006) }\end{array}$ \\
\hline & $\begin{array}{l}\text { Myocardial } \\
\text { infarction }\end{array}$ & Mouse & Intraperitonial & $\begin{array}{l}\text { Reduced myocardial infarct } \\
\text { size with treatment (two } \\
\text { doses) before ( } 1 \text { and } 6 \text { h) or } \\
\text { after ( } 1 \text { and } 5 \text { h) LAD ligation. }\end{array}$ & $\begin{array}{l}\text { (Vogler et al., } \\
\text { 2015) }\end{array}$ \\
\hline \multirow[t]{2}{*}{ GSK360A } & $\begin{array}{l}\text { Myocardial } \\
\text { infarction }\end{array}$ & Rat & Oral & $\begin{array}{l}\text { Improved heart ventricular } \\
\text { function (without effect on } \\
\text { infarct size) with treatment } \\
\text { over a } 28 \text {-day period starting } \\
48 \text { h after LAD ligation. }\end{array}$ & $\begin{array}{l}\text { (Bao et al., } \\
\text { 2010) }\end{array}$ \\
\hline & $\begin{array}{l}\text { Myocardial } \\
\text { infarction }\end{array}$ & Rat & Oral & $\begin{array}{l}\text { Reduced myocardial infarct } \\
\text { size with treatment at } 4 \mathrm{~h} \\
\text { prior to LAD ligation. }\end{array}$ & $\begin{array}{l}\text { (Ong et al., } \\
2014 \text { ) }\end{array}$ \\
\hline Kidn & & & & & \\
\hline
\end{tabular}




\begin{tabular}{|c|c|c|c|c|c|}
\hline GSK1002083A & Renal ischaemia & Mouse & Oral & $\begin{array}{l}\text { Improved renal function, } \\
\text { prevented development of } \\
\text { fibrosis, inflammation and } \\
\text { anaemia with pre-ischemic } \\
\text { treatment (two doses at } 48 \mathrm{~h} \\
\text { and } 6 \mathrm{~h} \text { prior to ischaemia) } \\
\text { but not post-ischemic } \\
\text { treatment (two doses at } 2 \text { and } \\
4 \text { days after ischaemia). }\end{array}$ & $\begin{array}{l}\text { (Kapitsinou et } \\
\text { al., 2012) }\end{array}$ \\
\hline \multirow[t]{2}{*}{ FG-4497 } & Renal ischaemia & Rat & Intravenous & $\begin{array}{l}\text { Improved renal blood flow } \\
\text { and protection of distal } \\
\text { tubules from injury in this ex } \\
\text { vivo AKI model with pre- } \\
\text { ischemic treatment (single } \\
\text { dose at } 6 \text { h prior to } \\
\text { ischaemia). }\end{array}$ & $\begin{array}{l}\text { (Rosenberger } \\
\text { et al., 2008) }\end{array}$ \\
\hline & $\begin{array}{l}\text { Renal allo- } \\
\text { transplantation }\end{array}$ & Rat & Intravenous & $\begin{array}{l}\text { Improved early and late graft } \\
\text { survival, reduced tubular } \\
\text { necrosis and improved renal } \\
\text { morphology with pre- } \\
\text { transplantation treatment of } \\
\text { donor animal (single dose at } 6 \\
\text { h prior to kidney } \\
\text { explantation). }\end{array}$ & $\begin{array}{l}\text { (Bernhardt et } \\
\text { al., 2009) }\end{array}$ \\
\hline FG-4487 & Renal ischaemia & Rat & Intraperitonial & $\begin{array}{l}\text { Improved renal function, } \\
\text { reduced tissue damage and } \\
\text { reduced apoptosis with pre- } \\
\text { ischemic treatment (single } \\
\text { dose at } 6 \text { h prior to } \\
\text { ischaemia). }\end{array}$ & $\begin{array}{l}\text { (Bernhardt et } \\
\text { al., 2006) }\end{array}$ \\
\hline FG-2216 & Renal ischaemia & Rat & Subcutaneous & $\begin{array}{l}\text { Improved renal function and } \\
\text { morphology with pre-ischemic } \\
\text { treatment (single dose at } 6 \mathrm{~h} \\
\text { prior to ischaemia) but not } \\
\text { post-ischemic treatment } \\
\text { (single dose after ischaemia, } 1 \\
\text { minute prior to reperfusion). }\end{array}$ & $\begin{array}{l}\text { (Wang et al., } \\
\text { 2012) }\end{array}$ \\
\hline
\end{tabular}




\begin{tabular}{|c|c|c|c|c|c|}
\hline GSK1278863 & Limb ischaemia & $\begin{array}{l}46 \\
\text { subjects } \\
\text { with } \\
\text { PAD }\end{array}$ & Oral & $\begin{array}{l}\text { No improvement on exercise } \\
\text { performance or increased in } \\
\text { HIF target genes expression in } \\
\text { PAD patients treated with } \\
\text { single dose or repeat doses } \\
\text { (once daily) over a 14-day } \\
\text { period. }\end{array}$ & $\begin{array}{l}\text { (Olson et al., } \\
2014 \text { ) }\end{array}$ \\
\hline
\end{tabular}

MCAO: middle cerebral artery occlusion, LAD: left anterior descending artery, AKI: acute kidney injury, PAD (peripheral artery disease).

Table 3: Inflammation

\begin{tabular}{|c|c|c|c|c|c|}
\hline Inhibitor & Disease model & Species & $\begin{array}{l}\text { Route of } \\
\text { administration }\end{array}$ & Outcome & References \\
\hline \multirow[t]{5}{*}{ FG-4497 } & Colitis & Mouse & Intraperitonial & $\begin{array}{l}\text { Attenuated weight loss and colon } \\
\text { shortening with treatment ( } 3 \text { doses; } \\
1 \text { day before, } 4 \text { hours before, } 1 \text { day } \\
\text { after TNBS administration). }\end{array}$ & $\begin{array}{l}\text { (Robinson et } \\
\text { al., 2008) }\end{array}$ \\
\hline & & & & $\begin{array}{l}\text { Reduced inflammatory infiltrate, } \\
\text { increased intact epithelium and } \\
\text { increased overall preservation of } \\
\text { tissue architecture. }\end{array}$ & \\
\hline & & & & $\begin{array}{l}\text { Decreased mRNA of TNF } \alpha \text { and IFN } \gamma \\
\text { (both inflammatory cytokines } \\
\text { associated with TNBS-induced } \\
\text { colitis) in epithelial-enriched colonic } \\
\text { scrapings. }\end{array}$ & \\
\hline & $\begin{array}{l}\text { Sepsis-induced } \\
\text { lung injury }\end{array}$ & Mouse & Intravenous & $\begin{array}{l}\text { Reduced lung injury and leukocyte } \\
\text { infiltration into the lung with pre- } \\
\text { treatment (single dose, } 3 \text { days } \\
\text { before LPS injection). }\end{array}$ & $\begin{array}{l}\text { (Gong et al., } \\
\text { 2015) }\end{array}$ \\
\hline & & & & $\begin{array}{l}\text { Improved survival rate with post- } \\
\text { treatment (single dose, } 2 \mathrm{~h} \text { after LPS } \\
\text { injection). }\end{array}$ & \\
\hline AKB-4924 & Colitis & Mouse & Subcutaneous & $\begin{array}{l}\text { Reduced weight loss, attenuated } \\
\text { colon shortening, reduced tissue } \\
\text { damage and reduced intestinal } \\
\text { permeability with repeat doses } \\
\text { (once daily) starting from } 24 \mathrm{~h} \\
\text { before TNBS-induced colitis up to } 7 \\
\text { days after. }\end{array}$ & $\begin{array}{l}\text { (Keely et al., } \\
\text { 2014) }\end{array}$ \\
\hline
\end{tabular}




\begin{tabular}{|c|c|c|c|c|c|}
\hline & Colitis & Mouse & $\begin{array}{l}\text { Oral and } \\
\text { intraperitonial }\end{array}$ & $\begin{array}{l}\text { Reduced weight loss, reduced tissue } \\
\text { inflammation, increased mucosal } \\
\text { barrier function with repeat doses } \\
\text { (once every } 48 \text { h) starting from } 24 \mathrm{~h} \\
\text { before TNBS-induced colitis up to } 7 \\
\text { days after. }\end{array}$ & $\begin{array}{l}\text { (Marks et al., } \\
\text { 2015) }\end{array}$ \\
\hline & Skin abscess & Mouse & Intralesion & $\begin{array}{l}\text { Reduced lesion size with repeat } \\
\text { doses ( } 3 \text { doses at 0, } 6 \text { and } 24 \text { h) after } \\
\text { subcutaneous injection of } \\
\text { Staphylococcus aureus (MSSA strain) }\end{array}$ & $\begin{array}{l}\text { (Okumura et } \\
\text { al., 2012) }\end{array}$ \\
\hline & $\begin{array}{l}\text { LPS-induced } \\
\text { inflammation }\end{array}$ & Mouse & Intradermal & $\begin{array}{l}\text { Enhanced neutrophil recruitment to } \\
\text { site of simultaneous inject of LPS } \\
\text { and inhibitor. }\end{array}$ & $\begin{array}{l}\text { (Leire et al., } \\
\text { 2013) }\end{array}$ \\
\hline & UTI & Mouse & Transurethral & $\begin{array}{l}\text { Reduced bacterial burden in the } \\
\text { urine, bladder and kidneys with } \\
\text { single dose treatment at } 1 \mathrm{~h} \text { prior to } \\
\text { UPEC injection. } \\
\text { Decreased in pro-inflammatory } \\
\text { cytokine release and neutrophil } \\
\text { activity in the bladders and kidneys. }\end{array}$ & $\begin{array}{l}\text { (Lin et al., } \\
2015 \text { ) }\end{array}$ \\
\hline GSK360A & Lactic acidosis & Mouse & Oral & $\begin{array}{l}\text { Attenuated the increase in blood } \\
\text { lactate level and increased survival } \\
\text { rate with treatment immediately } \\
\text { after LPS injection. }\end{array}$ & $\begin{array}{l}\text { (Suhara et } \\
\text { al., 2015) }\end{array}$ \\
\hline
\end{tabular}

TNBS: trinitrobenzene sulfonic acid, TNF $\alpha$ : tumour necrosis factor- $\alpha$; IFN $\gamma$ : interferon- $\gamma$, MSSA: methicillinsensitive strains, LPS: lipopolysaccharide, UTI: urinary tract infection, UPEC: uropathogenic Eschericia coli. 


\section{References}

Adam, J., Hatipoglu, E., O'Flaherty, L., Ternette, N., Sahgal, N., Lockstone, H., Baban, D., Nye, E., Stamp, G.W., Wolhuter, K., Stevens, M., Fischer, R., Carmeliet, P., Maxwell, P.H., Pugh, C.W., Frizzell, N., Soga, T., Kessler, B.M., El-Bahrawy, M., Ratcliffe, P.J., Pollard, P.J., 2011. Renal cyst formation in Fh1-deficient mice is independent of the Hif/Phd pathway: roles for fumarate in KEAP1 succination and Nrf2 signaling. Cancer Cell 20 (4), 524-537.

Aik, W., Demetriades, M., Hamdan, M.K., Bagg, E.A., Yeoh, K.K., Lejeune, C., Zhang, Z., McDonough, M.A., Schofield, C.J., 2013. Structural basis for inhibition of the fat mass and obesity associated protein (FTO). Journal of Medicinal Chemistry 56 (9), 3680-3688.

Aik, W., McDonough, M.A., Thalhammer, A., Chowdhury, R., Schofield, C.J., 2012. Role of the jelly-roll fold in substrate binding by 2-oxoglutarate oxygenases. Current Opinion in Structural Biology $22(6), 691-700$.

Aik, W., Scotti, J.S., Choi, H., Gong, L., Demetriades, M., Schofield, C.J., McDonough, M.A., 2014. Structure of human RNA N6-methyladenine demethylase ALKBH5 provides insights into its mechanisms of nucleic acid recognition and demethylation. Nucleic acids research 42 (7), 47414754.

Aik, W.S., Chowdhury, R., Clifton, I.J., Hopkinson, R.J., Leissing, T., McDonough, M.A., Nowak, R., Schofield, C.J., Walport, L.J., 2015. Introduction to Structural Studies on 2-OxoglutarateDependent Oxygenases and Related Enzymes, 2-Oxoglutarate-Dependent Oxygenases. The Royal Society of Chemistry, pp. 59-94.

Ang, S.O., Chen, H., Hirota, K., Gordeuk, V.R., Jelinek, J., Guan, Y., Liu, E., Sergueeva, A.I., Miasnikova, G.Y., Mole, D., Maxwell, P.H., Stockton, D.W., Semenza, G.L., Prchal, J.T., 2002. Disruption of oxygen homeostasis underlies congenital Chuvash polycythemia. Nature Genetics 32, 614-621.

Appelhoff, R.J., Tian, Y.M., Raval, R.R., Turley, H., Harris, A.L., Pugh, C.W., Ratcliffe, P.J., Gleadle, J.M., 2004. Differential function of the prolyl hydroxylases PHD1, PHD2 and PHD3 in the regulation of hypoxia-inducible factor. Journal of Biological Chemistry 279 (37), 38458-38465.

Aragones, J., Schneider, M., Van Geyte, K., Fraisl, P., Dresselaers, T., Mazzone, M., Dirkx, R., Zacchigna, S., Lemieux, H., Jeoung, N.H., Lambrechts, D., Bishop, T., Lafuste, P., Diez-Juan, A., Harten, S.K., Van Noten, P., De Bock, K., Willam, C., Tjwa, M., Grosfeld, A., Navet, R., Moons, L., Vandendriessche, T., Deroose, C., Wijeyekoon, B., Nuyts, J., Jordan, B., Silasi-Mansat, R., Lupu, F., Dewerchin, M., Pugh, C., Salmon, P., Mortelmans, L., Gallez, B., Gorus, F., Buyse, J., Sluse, F., Harris, R.A., Gnaiger, E., Hespel, P., Van Hecke, P., Schuit, F., Van Veldhoven, P., Ratcliffe, P., Baes, M., Maxwell, P., Carmeliet, P., 2008. Deficiency or inhibition of oxygen sensor Phd1 induces hypoxia tolerance by reprogramming basal metabolism. Nature Genetics 40 (2), 170180.

Arsenault, P.R., Pei, F., Lee, R., Kerestes, H., Percy, M.J., Keith, B., Simon, M.C., Lappin, T.R., Khurana, T.S., Lee, F.S., 2013. A Knockin Mouse Model of Human PHD2-Associated Erythrocytosis Establishes a Haploinsufficiency Mechanism. Journal of Biological Chemistry 288 (47), 3357133584.

Bachmann, S., Le Hir, M., Eckardt, K.-U., 1993. Co-localization of erythropoietin messenger RNA and ecto-5'-nucleotidase immunoreactivity in peritubular cells of rat renal cortex indicates that fibroblasts produce erythropoietin. J. Histochem. Cytochem. 41, 335-341.

Bao, W., Qin, P., Needle, S., Erickson-Miller, C.L., Duffy, K.J., Ariazi, J.L., Zhao, S., Olzinski, A.R., Behm, D.J., Pipes, G.C., Jucker, B.M., Hu, E., Lepore, J.J., Willette, R.N., 2010. Chronic inhibition of hypoxia-inducible factor prolyl 4-hydroxylase improves ventricular performance, remodeling, and vascularity after myocardial infarction in the rat. Journal of Cardiovascular Pharmacology 56 (2), 147-155.

Barrett, T.D., Palomino, H.L., Brondstetter, T.I., Kanelakis, K.C., Wu, X., Haug, P.V., Yan, W., Young, A., Hua, H., Hart, J.C., Tran, D.T., Venkatesan, H., Rosen, M.D., Peltier, H.M., Sepassi, K., Rizzolio, M.C., Bembenek, S.D., Mirzadegan, T., Rabinowitz, M.H., Shankley, N.P., 2011. Pharmacological 
characterization of 1-(5-chloro-6-(trifluoromethoxy)-1H-benzoimidazol-2-yl)-1H-pyrazole-4carboxylic acid (JNJ-42041935), a potent and selective hypoxia-inducible factor prolyl hydroxylase inhibitor. Molecular Pharmacology 79 (6), 910-920.

Barrett, T.D., Palomino, H.L., Brondstetter, T.I., Kanelakis, K.C., Wu, X., Yan, W., Merton, K.P., Schoetens, F., Ma, J.Y., Skaptason, J., Gao, J., Tran, D.T., Venkatesan, H., Rosen, M.D., Shankley, N.P., Rabinowitz, M.H., 2015. Prolyl hydroxylase inhibition corrects functional iron deficiency and inflammation-induced anaemia in rats. British Journal of Pharmacology 172 (16), 40784088.

Berk, L., Burchenal, J.H., Castle, W.B., 1949. Erythropoietic effect of cobalt in patients with or without anemia. New England Journal of Medicine 240 (19), 754-761.

Bernhardt, W.M., Campean, V., Kany, S., Jurgensen, J.S., Weidemann, A., Warnecke, C., Arend, M., Klaus, S., Gunzler, V., Amann, K., Willam, C., Wiesener, M.S., Eckardt, K.U., 2006. Preconditional activation of hypoxia-inducible factors ameliorates ischemic acute renal failure. Journal of the American Society of Nephrology 17 (7), 1970-1978.

Bernhardt, W.M., Gottmann, U., Doyon, F., Buchholz, B., Campean, V., Schodel, J., Reisenbuechler, A., Klaus, S., Arend, M., Flippin, L., Willam, C., Wiesener, M.S., Yard, B., Warnecke, C., Eckardt, K.U., 2009. Donor treatment with a PHD-inhibitor activating HIFs prevents graft injury and prolongs survival in an allogenic kidney transplant model. Proceedings of the National Academy of Sciences, U.S.A. 106 (50), 21276-21281.

Bernhardt, W.M., Wiesener, M.S., Scigalla, P., Chou, J., Schmieder, R.E., Gunzler, V., Eckardt, K.U., 2010. Inhibition of prolyl hydroxylases increases erythropoietin production in ESRD. Journal of the American Society of Nephrology 21 (12), 2151-2156.

Berra, E., Benizri, E., Ginouves, A., Volmat, V., Roux, D., Pouyssegur, J., 2003. HIF prolyl-hydroxylase 2 is the key oxygen sensor setting low steady-state levels of HIF-1alpha in normoxia. EMBO Journal 22 (16), 4082-4090.

Besarab, A., Bolton, W.K., Browne, J.K., Egrie, J.C., Nissenson, A.R., Okamoto, D.M., Schwab, S.J., Goodkin, D.A., 1998. The Effects of Normal as Compared with Low Hematocrit Values in Patients with Cardiac Disease Who Are Receiving Hemodialysis and Epoetin. New England Journal of Medicine 339 (9), 584-590.

Besarab, A., Chernyavskaya, E., Motylev, I., Shutov, E., Kumbar, L.M., Gurevich, K., Chan, D.T., Leong, R., Poole, L., Zhong, M., Saikali, K.G., Franco, M., Hemmerich, S., Yu, K.P., Neff, T.B., 2015a. Roxadustat (FG-4592): Correction of Anemia in Incident Dialysis Patients. Journal of the American Society of Nephrology In Press.

Besarab, A., Provenzano, R., Hertel, J., Zabaneh, R., Klaus, S.J., Lee, T., Leong, R., Hemmerich, S., Yu, K.-H.P., Neff, T.B., 2015b. Randomized placebo-controlled dose-ranging and pharmacodynamics study of roxadustat (FG-4592) to treat anemia in nondialysis-dependent chronic kidney disease (NDD-CKD) patients. Nephrology Dialysis Transplantation 30 (10), 1665-1673.

Beyer, S., Kristensen, M.M., Jensen, K.S., Johansen, J.V., Staller, P., 2008. The Histone Demethylases JMJD1A and JMJD2B Are Transcriptional Targets of Hypoxia-inducible Factor HIF. Journal of Biological Chemistry 283 (52), 36542-36552.

Bishop, T., Ratcliffe, P.J., 2015. HIF hydroxylase pathways in cardiovascular physiology and medicine. Circ Res 117 (1), 65-79.

Botusan, I.R., Sunkari, V.G., Savu, O., Catrina, A.I., Grunler, J., Lindberg, S., Pereira, T., Yla-Herttuala, S., Poellinger, L., Brismar, K., Catrina, S.B., 2008. Stabilization of HIF-1alpha is critical to improve wound healing in diabetic mice. Proceedings of the National Academy of Sciences, USA 105 (49), 19426-19431.

Brookhart, M.A., Schneeweiss, S., Avorn, J., Bradbury, B.D., Rothman, K.J., Fischer, M., Mehta, J., Winkelmayer, W.C., 2008. The effect of altitude on dosing and response to erythropoietin in ESRD. Journal of the American Society of Nephrology 19 (7), 1389-1395.

Bruick, R.K., McKnight, S.L., 2001. A conserved family of prolyl-4-hydroxylases that modify HIF. Science 294, 1337-1340. 
Chan, M.C., Atasoylu, O., Hodson, E., Tumber, A., Leung, I.K., Chowdhury, R., Gomez-Perez, V., Demetriades, M., Rydzik, A.M., Holt-Martyn, J., Tian, Y.M., Bishop, T., Claridge, T.D., Kawamura, A., Pugh, C.W., Ratcliffe, P.J., Schofield, C.J., 2015. Potent and Selective Triazole-Based Inhibitors of the Hypoxia-Inducible Factor Prolyl-Hydroxylases with Activity in the Murine Brain. PLoS One 10 (7), e0132004.

Chen, R.L., Ogunshola, O.O., Yeoh, K.K., Jani, A., Papadakis, M., Nagel, S., Schofield, C.J., Buchan, A.M., 2014. HIF prolyl hydroxylase inhibition prior to transient focal cerebral ischaemia is neuroprotective in mice. Journal of Neurochemistry 131 (2), 177-189.

Cho, H., Park, H., Yang, E.G., 2005. A fluorescence polarization-based interaction assay for hypoxiainducible factor prolyl hydroxylases. Biochemical and Biophysical Research Communications 337 (1), 275-280.

Choi, K.O., Lee, T., Lee, N., Kim, J.H., Yang, E.G., Yoon, J.M., Kim, J.H., Lee, T.G., Park, H., 2005. Inhibition of the catalytic activity of hypoxia-inducible factor-1alpha-prolyl-hydroxylase 2 by a MYND-type zinc finger. Mol Pharmacol 68 (6), 1803-1809.

Choudhry, H., Schodel, J., Oikonomopoulos, S., Camps, C., Grampp, S., Harris, A.L., Ratcliffe, P.J., Ragoussis, J., Mole, D.R., 2014. Extensive regulation of the non-coding transcriptome by hypoxia: role of HIF in releasing paused RNApol2. EMBO Reports 15 (1), 70-76.

Chowdhury, R., Candela-Lena, J.I., Chan, M.C., Greenald, D.J., Yeoh, K.K., Tian, Y.M., McDonough, M.A., Tumber, A., Rose, N.R., Conejo-Garcia, A., Demetriades, M., Mathavan, S., Kawamura, A., Lee, M.K., van Eeden, F., Pugh, C.W., Ratcliffe, P.J., Schofield, C.J., 2013. Selective small molecule probes for the hypoxia inducible factor (HIF) prolyl hydroxylases. ACS chemical biology 8 (7), 1488-1496.

Chowdhury, R., McDonough, M.A., Mecinovic, J., Loenarz, C., Flashman, E., Hewitson, K.S., Domene, C., Schofield, C.J., 2009. Structural basis for binding of hypoxia-inducible factor to the oxygensensing prolyl hydroxylases. Structure 17 (7), 981-989.

Clambey, E.T., McNamee, E.N., Westrich, J.A., Glover, L.E., Campbell, E.L., Jedlicka, P., de Zoeten, E.F., Cambier, J.C., Stenmark, K.R., Colgan, S.P., Eltzschig, H.K., 2012. Hypoxia-inducible factor-1 alpha-dependent induction of FoxP3 drives regulatory T-cell abundance and function during inflammatory hypoxia of the mucosa. Proceedings of the National Academy of Sciences, U.S.A. 109 (41), E2784-2793.

Cockman, M.E., Webb, J.D., Kramer, H.B., Kessler, B.M., Ratcliffe, P.J., 2009a. Proteomics-based identification of novel factor inhibiting hypoxia-inducible factor (FIH) substrates indicates widespread asparaginyl hydroxylation of ankyrin repeat domain-containing proteins. Molecular \& Cellular Proteomics 8 (3), 535-546.

Cockman, M.E., Webb, J.D., Ratcliffe, P.J., 2009b. FIH-dependent asparaginyl hydroxylation of ankyrin repeat domain-containing proteins. Annals of the New York Academy of Sciences 1177, 9-18.

Coleman, M.L., McDonough, M.A., Hewitson, K.S., Coles, C., Mecinovic, J., Edelmann, M., Cook, K.M., Cockman, M.E., Lancaster, D.E., Kessler, B.M., Oldham, N.J., Ratcliffe, P.J., Schofield, C.J., 2007. Asparaginyl hydroxylation of the Notch ankyrin repeat domain by factor inhibiting hypoxiainducible factor. Journal of Biological Chemistry 282 (33), 24027-24038.

Dames, S.A., Martinez-Yamout, M., Guzman, R.N.D., Dyson, H.J., Wright, P.E., 2002. Structural basis for hif-1 $\alpha / C B P$ recognition in the cellular hypoxic response. Proceedings of the National Academy of Sciences, USA 99 (8), 5271-5276.

Dang, E.V., Barbi, J., Yang, H.Y., Jinasena, D., Yu, H., Zheng, Y., Bordman, Z., Fu, J., Kim, Y., Yen, H.R., Luo, W., Zeller, K., Shimoda, L., Topalian, S.L., Semenza, G.L., Dang, C.V., Pardoll, D.M., Pan, F., 2011. Control of $T(H) 17 / T(r e g)$ balance by hypoxia-inducible factor 1. Cell 146 (5), 772-784.

Dann, C.E.I., Bruick, R.K., Deisenhofer, J., 2002. Structure of factor-inhibiting hypoxia-inducible factor 1: an asparaginyl hydroxylase involved in the hypoxic response pathway. Proceedings of the National Academy of Sciences, USA 99 (24), 15351-15356.

Dao, J.H., Kurzeja, R.J., Morachis, J.M., Veith, H., Lewis, J., Yu, V., Tegley, C.M., Tagari, P., 2009. Kinetic characterization and identification of a novel inhibitor of hypoxia-inducible factor prolyl 
hydroxylase 2 using a time-resolved fluorescence resonance energy transfer-based assay technology. Analytical Biochemistry 384 (2), 213-223.

Dayan, F., Monticelli, M., Pouyssegur, J., Pecou, E., 2009. Gene regulation in response to graded hypoxia: the non-redundant roles of the oxygen sensors PHD and FIH in the HIF pathway. Journal of Theoretical Biology 259 (2), 304-316.

Dayan, F., Roux, D., Brahimi-Horn, M.C., Pouyssegur, J., Mazure, N.M., 2006. The oxygen sensor factorinhibiting hypoxia-inducible factor-1 controls expression of distinct genes through the bifunctional transcriptional character of hypoxia-inducible factor-1alpha. Cancer Research 66 (7), 3688-3698.

Demetriades, M., Leung, I.K., Chowdhury, R., Chan, M.C., McDonough, M.A., Yeoh, K.K., Tian, Y.M., Claridge, T.D., Ratcliffe, P.J., Woon, E.C., Schofield, C.J., 2012. Dynamic combinatorial chemistry employing boronic acids/boronate esters leads to potent oxygenase inhibitors. Angew Chem Int Ed Engl 51 (27), 6672-6675.

Deshmane, S.L., Amini, S., Sen, S., Khalili, K., Sawaya, B.E., 2011. Regulation of the HIV-1 promoter by HIF-1alpha and Vpr proteins. Virology Journal 8, 477.

Drüeke, T., 2001. Hyporesponsiveness to recombinant human erythropoietin. Nephrology Dialysis Transplantation 16 (suppl 7), 25-28.

Ehrismann, D., Flashman, E., Genn, D.N., Mathioudakis, N., Hewitson, K.S., Ratcliffe, P.J., Schofield, C.J., 2007. Studies on the activity of the hypoxia-inducible factor hydroxylases using an oxygen consumption assay. Biochemical Journal 401, 227-234.

Elkins, J.M., Hewitson, K.S., McNeill, L.A., Seibel, J.F., Schlemminger, I., Pugh, C.W., Ratcliffe, P.J., Schofield, C.J., 2003. Structure of factor-inhibiting hypoxia-inducible factor (HIF) reveals mechanism of oxidative modification of HIF-1 alpha. Journal of Biological Chemistry 278 (3), 1802-1806.

Eltzschig, H.K., Bratton, D.L., Colgan, S.P., 2014. Targeting hypoxia signalling for the treatment of ischaemic and inflammatory diseases. Nature Reviews Drug Discovery 13 (11), 852-869.

Eltzschig, H.K., Carmeliet, P., 2011a. Hypoxia and inflammation. New England Journal of Medicine 364 (7), 656-665.

Eltzschig, H.K., Eckle, T., 2011b. Ischemia and reperfusion[mdash]from mechanism to translation. Nature Medicine 17 (11), 1391-1401.

Epstein, A.C.R., Gleadle, J.M., McNeill, L.A., Hewitson, K.S., O'Rourke, J., Mole, D.R., Mukherji, M., Metzen, E., Wilson, M.I., Dhanda, A., Tian, Y.-M., Masson, N., Hamilton, D.L., Jaakkola, P., Barstead, R., Hodgkin, J., Maxwell, P.H., Pugh, C.W., Schofield, C.J., Ratcliffe, P.J., 2001. C. elegans EGL-9 and mammalian homologues define a family of dioxygenases that regulate HIF by prolyl hydroxylation. Cell 107, 43-54.

Flagg, S.C., Giri, N., Pektas, S., Maroney, M.J., Knapp, M.J., 2012. Inverse solvent isotope effects demonstrate slow aquo release from hypoxia inducible factor-prolyl hydroxylase (PHD2). Biochemistry 51 (33), 6654-6666.

Flamme, I., Oehme, F., Ellinghaus, P., Jeske, M., Keldenich, J., Thuss, U., 2014. Mimicking hypoxia to treat anemia: HIF-stabilizer BAY 85-3934 (Molidustat) stimulates erythropoietin production without hypertensive effects. PLoS One 9 (11), e111838.

Flashman, E., Hoffart, L.M., Hamed, R.B., Bollinger, J.M., Jr., Krebs, C., Schofield, C.J., 2010. Evidence for the slow reaction of hypoxia-inducible factor prolyl hydroxylase 2 with oxygen. FEBS Journal 277 (19), 4089-4099.

Fraisl, P., Aragones, J., Carmeliet, P., 2009. Inhibition of oxygen sensors as a therapeutic strategy for ischaemic and inflammatory disease. Nature Reviews Drug Discovery 8 (2), 139-152.

Freedman, S.J., Sun, Z.-Y.J., Poy, F., Kung, A.L., Livingston, D.M., Wagner, G., Eck, M.J., 2002. Structural basis for recruitment of $\mathrm{CBP} / \mathrm{p} 300$ by hypoxia-inducible factor- $1 \alpha$. Proceedings of the National Academy of Sciences, USA 99 (8), 5367-5372. 
Furuta, G.T., Turner, J.R., Taylor, C.T., Hershberg, R.M., Comerford, K., Narravula, S., Podolsky, D.K., Colgan, S.P., 2001. Hypoxia-inducible factor 1-dependent induction of intestinal trefoil factor protects barrier function during hypoxia. Journal of Experimental Medicine 193 (9), 1027-1034.

Gong, H., Rehman, J., Tang, H., Wary, K., Mittal, M., Chaturvedi, P., Zhao, Y.Y., Komarova, Y.A., Vogel, S.M., Malik, A.B., 2015. HIF2alpha signaling inhibits adherens junctional disruption in acute lung injury. Journal of Clinical Investigation 125 (2), 652-664.

Haase, V.H., 2013. Regulation of erythropoiesis by hypoxia-inducible factors. Blood Reviews 27 (1), 4153.

Hardy, A.P., Prokes, I., Kelly, L., Campbell, I.D., Schofield, C.J., 2009. Asparaginyl beta-hydroxylation of proteins containing ankyrin repeat domains influences their stability and function. Journal of Molecular Biology 392 (4), 994-1006.

Hausinger, R.P., 2004. Fe(II)/alpha-ketoglutarate-dependent hydroxylases and related enzymes Critical Reviews in Biochemistry and Molecular Biology 39, 21-68.

Hausinger, R.P., 2015. Biochemical Diversity of 2-Oxoglutarate-Dependent Oxygenases, 2Oxoglutarate-Dependent Oxygenases. The Royal Society of Chemistry, pp. 1-40.

Hewitson, K.S., Lienard, B.M., McDonough, M.A., Clifton, I.J., Butler, D., Soares, A.S., Oldham, N.J., McNeill, L.A., Schofield, C.J., 2007a. Structural and mechanistic studies on the inhibition of the hypoxia-inducible transcription factor hydroxylases by tricarboxylic acid cycle intermediates. Journal of Biologcial Chemistry 282 (5), 3293-3301.

Hewitson, K.S., McNeill, L.A., M.V., R., Tian, Y.-M., Bullock, A.N., Welford, R.W., Elkins, J.M., Oldham, N.J., Bhattacharya, S., Gleadle, J.M., Ratcliffe, P.J., Pugh, C.W., Schofield, C.J., 2002. Hypoxia inducible factor (HIF) asparagine hydroxylase is identical to Factor Inhibiting HIF (FIH) and is related to the cupin structural family. Journal of Biological Chemistry 277 (29), 26351-26355.

Hewitson, K.S., Schofield, C.J., Ratcliffe, P.J., 2007b. Hypoxia-inducible factor prolyl-hydroxylase: purification and assays of PHD2. Methods in Enzymology 435, 25-42.

Higgins, D.F., Kimura, K., Bernhardt, W.M., Shrimanker, N., Akai, Y., Hohenstein, B., Saito, Y., Johnson, R.S., Kretzler, M., Cohen, C.D., Eckardt, K.U., Iwano, M., Haase, V.H., 2007. Hypoxia promotes fibrogenesis in vivo via HIF-1 stimulation of epithelial-to-mesenchymal transition. Journal of Clinical Investigation 117 (12), 3810-3820.

Hirsila, M., Koivunen, P., Gunzler, V., Kivirikko, K.I., Myllyharju, J., 2003. Characterization of the human prolyl 4-hydroxylases that modify the hypoxia-inducible factor HIF. Journal of Biological Chemistry 278 (13), 30772-30780.

Holdstock, L., Meadowcroft, A.M., Maier, R., Johnson, B.M., Jones, D., Rastogi, A., Zeig, S., Lepore, J.J., Cobitz, A.R., 2015. Four-Week Studies of Oral Hypoxia-Inducible Factor-Prolyl Hydroxylase Inhibitor GSK1278863 for Treatment of Anemia. Journal of the American Society of Nephrology In Press.

Holscher, M., Silter, M., Krull, S., von Ahlen, M., Hesse, A., Schwartz, P., Wielockx, B., Breier, G., Katschinski, D.M., Zieseniss, A., 2011. Cardiomyocyte-specific prolyl-4-hydroxylase domain 2 knock out protects from acute myocardial ischemic injury. Journal of Biological Chemistry 286 (13), 11185-11194.

Hsieh, M.M., Linde, N.S., Wynter, A., Metzger, M., Wong, C., Langsetmo, I., Lin, A., Smith, R., Rodgers, G.P., Donahue, R.E., Klaus, S.J., Tisdale, J.F., 2007. HIF prolyl hydroxylase inhibition results in endogenous erythropoietin induction, erythrocytosis, and modest fetal hemoglobin expression in rhesus macaques. Blood 110 (6), 2140-2147.

https://clinicaltrials.gov/ct2/show/NCT01831804?term=1278863\&rank=17, Safety, Tolerability, Pharmacokinetics and Pharmacodynamics Study of Single and Repeated Doses of Topical GSK1278863.

Hyvarinen, J., Hassinen, I.E., Sormunen, R., Maki, J.M., Kivirikko, K.I., Koivunen, P., Myllyharju, J., 2010. Hearts of hypoxia-inducible factor prolyl 4-hydroxylase-2 hypomorphic mice show protection against acute ischemia-reperfusion injury. Journal of Biological Chemistry 285 (18), 1364613657. 
Ivan, M., Haberberger, T., Gervasi, D.C., Michelson, K.S., Gunzler, V., Kondo, K., Yang, H., Sorokina, I., Conaway, R.C., Conaway, J.W., Kaelin, W.G.J., 2002. Biochemical purification and pharmacological inhibition of a mammalian prolyl hydroxylase acting on hypoxia-inducible factor. Proceedings of the National Academy of Sciences, USA 99 (21), 13459-13464.

Ivan, M., Kondo, K., Yang, H., Kim, W., Valiando, J., Ohh, M., Salic, A., Asara, J.M., Lane, W.S., Kaelin, W.G.J., 2001. HIF $\alpha$ targeted for VHL-mediated destruction by proline hydroxylation: implications for $\mathrm{O}_{2}$ sensing. Science 292, 464-468.

Jaakkola, P., Mole, D.R., Tian, Y.-M., Wilson, M.I., Gielbert, J., Gaskell, S.J., Kriegsheim, A.v., Hebestreit, H.F., Mukherji, M., Schofield, C.J., Maxwell, P.H., Pugh, C.W., Ratcliffe, P.J., 2001. Targeting of HIF- $\alpha$ to the von Hippel-Lindau ubiquitylation complex by $\mathrm{O}_{2}$-regulated prolyl hydroxylation. Science 292 (5516), 468-472.

Jelkmann, W., 2011. Regulation of erythropoietin production. Journal of Physiology 589 (Pt 6), 12511258.

Johnson, B., Stier, B., Caltabiano, S., 2014. Effect of food and gemfibrozil on the pharmacokinetics of the novel prolyl hydroxylase inhibitor GSK1278863. Clinical Pharmacology in Drug Development 3 (2), 109-117.

Kalucka, J., Ettinger, A., Franke, K., Mamlouk, S., Singh, R.P., Farhat, K., Muschter, A., Olbrich, S., Breier, G., Katschinski, D.M., Huttner, W., Weidemann, A., Wielockx, B., 2013. Loss of epithelial hypoxia-inducible factor prolyl hydroxylase 2 accelerates skin wound healing in mice. Molecular and Cellular Biology 33 (17), 3426-3438.

Kapitsinou, P.P., Jaffe, J., Michael, M., Swan, C.E., Duffy, K.J., Erickson-Miller, C.L., Haase, V.H., 2012. Preischemic targeting of HIF prolyl hydroxylation inhibits fibrosis associated with acute kidney injury. American Journal of Physiology - Renal Physiology 302 (9), F1172-1179.

Kaule, G., Gunzler, V., 1990. Assay for 2-oxoglutarate decarboxylating enzymes based on the determination of [1-14C]succinate: application to prolyl 4-hydroxylase. Analytical Biochemistry 184 (2), 291-297.

Kawamura, A., Loenarz, C., Schofield, C.J., 2011. Mutations to metabolic enzymes in cancer herald a need to unify genetics and biochemistry. Cell Cycle 10 (17), 2819-2820.

Keely, S., Campbell, E.L., Baird, A.W., Hansbro, P.M., Shalwitz, R.A., Kotsakis, A., McNamee, E.N., Eltzschig, H.K., Kominsky, D.J., Colgan, S.P., 2014. Contribution of epithelial innate immunity to systemic protection afforded by prolyl hydroxylase inhibition in murine colitis. Mucosal immunology 7 (1), 114-123.

Keith, B., Johnson, R.S., Simon, M.C., 2012. HIF1alpha and HIF2alpha: sibling rivalry in hypoxic tumour growth and progression. Nature Reviews Cancer 12 (1), 9-22.

Kempf, V.A., Lebiedziejewski, M., Alitalo, K., Walzlein, J.H., Ehehalt, U., Fiebig, J., Huber, S., Schutt, B., Sander, C.A., Muller, S., Grassl, G., Yazdi, A.S., Brehm, B., Autenrieth, I.B., 2005. Activation of hypoxia-inducible factor-1 in bacillary angiomatosis: evidence for a role of hypoxia-inducible factor-1 in bacterial infections. Circulation 111 (8), 1054-1062.

Klaus, S.J., Neff, T.B., 2006. Treatment Method For Anemia. FibroGen,Inc, United States.

Klose, R.J., Kallin, E.M., Zhang, Y., 2006. JmjC-domain-containing proteins and histone demethylation. Nature Reviews Genetics 7, 715-727.

Klose, R.J., Zhang, Y., 2007. Regulation of histone methylation by demethylimination and demethylation. Nature Reviews Molecular Cell Biology 8 (4), 307-318.

Koivunen, P., Hirsila, M., Gunzler, V., Kivirikko, K.I., Myllyharju, J., 2004. Catalytic properties of the asparaginyl hydroxylase $(\mathrm{FIH})$ in the oxygen sensing pathway are distinct from those of its prolyl4-hydroxylases. Journal of Biological Chemistry 279 (11), 9899-9904.

Koivunen, P., Hirsila, M., Remes, A.M., Hassinen, I.E., Kivirikko, K.I., Myllyharju, J., 2007. Inhibition of hypoxia-inducible factor (HIF) hydroxylases by citric acid cycle intermediates: possible links between cell metabolism and stabilization of HIF. Journal of Biological Chemistry 282 (7), 45244532. 
Koivunen, P., Lee, S., Duncan, C.G., Lopez, G., Lu, G., Ramkissoon, S., Losman, J.A., Joensuu, P., Bergmann, U., Gross, S., Travins, J., Weiss, S., Looper, R., Ligon, K.L., Verhaak, R.G., Yan, H., Kaelin, W.G., Jr., 2012. Transformation by the (R)-enantiomer of 2-hydroxyglutarate linked to EGLN activation. Nature 483 (7390), 484-488.

Koury, M.J., Haase, V.H., 2015. Anaemia in kidney disease: harnessing hypoxia responses for therapy. Nature reviews. Nephrology 11 (7), 394-410.

Krebs, C., Galonic Fujimori, D., Walsh, C.T., Bollinger, J.M., Jr., 2007. Non-heme Fe(IV)-oxo intermediates. Acc Chem Res 40 (7), 484-492.

Kulshreshtha, R., Ferracin, M., Wojcik, S.E., Garzon, R., Alder, H., Agosto-Perez, F.J., Davuluri, R., Liu, C.G., Croce, C.M., Negrini, M., Calin, G.A., Ivan, M., 2007. A microRNA signature of hypoxia. Molecular and Cellular Biology 27 (5), 1859-1867.

Lancaster, D.E., McNeill, L.A., McDonough, M.A., Aplin, R.T., Hewitson, K.S., Pugh, C.W., Ratcliffe, P.J., Schofield, C.J., 2004. Disruption of dimerization and substrate phosphorylation inhibit factor inhibiting hypoxia-inducible factor (FIH) activity. Biochemical Journal 383, 429-437.

Landazuri, M.O., Vara-Vega, A., Viton, M., Cuevas, Y., del Peso, L., 2006. Analysis of HIF-prolyl hydroxylases binding to substrates. Biochemical and Biophysical Research Communications 351 (2), 313-320.

Lando, D., Peet, D.J., Gorman, J.J., Whelan, D.A., Whitelaw, M.L., Bruick, R.K., 2002a. FIH-1 is an asparaginyl hydroxylase enzyme that regulates the transcriptional activity of hypoxia-inducible factor. Genes \& Development 16 (12), 1466-1471.

Lando, D., Peet, D.J., Whelan, D.A., Gorman, J.J., Whitelaw, M.L., 2002b. Asparagine hydroxylation of the HIF transactivation domain: a hypoxic switch. Science 295, 858-861.

Lee, S.H., Jeong Hee, M., Eun Ah, C., Ryu, S.E., Myung Kyu, L., 2008. Monoclonal antibody-based screening assay for factor inhibiting hypoxia-inducible factor inhibitors. Journal of Biomolecular Screening 13 (6), 494-503.

Leire, E., Olson, J., Isaacs, H., Nizet, V., Hollands, A., 2013. Role of hypoxia inducible factor-1 in keratinocyte inflammatory response and neutrophil recruitment. Journal of Inflammation 10 (1), 28.

Leung, I.K., Demetriades, M., Hardy, A.P., Lejeune, C., Smart, T.J., Szollossi, A., Kawamura, A., Schofield, C.J., Claridge, T.D., 2013. Reporter ligand NMR screening method for 2-oxoglutarate oxygenase inhibitors. Journal of Medicinal Chemistry 56 (2), 547-555.

Leung, I.K., Flashman, E., Yeoh, K.K., Schofield, C.J., Claridge, T.D., 2010a. Using NMR solvent water relaxation to investigate metalloenzyme-ligand binding interactions. Journal of Medicinal Chemistry 53 (2), 867-875.

Leung, I.K., Krojer, T.J., Kochan, G.T., Henry, L., von Delft, F., Claridge, T.D., Oppermann, U., McDonough, M.A., Schofield, C.J., 2010b. Structural and mechanistic studies on gammabutyrobetaine hydroxylase. Chemistry \& biology 17 (12), 1316-1324.

Lin, A.E., Beasley, F.C., Olson, J., Keller, N., Shalwitz, R.A., Hannan, T.J., Hultgren, S.J., Nizet, V., 2015. Role of Hypoxia Inducible Factor-1alpha (HIF-1alpha) in Innate Defense against Uropathogenic Escherichia coli Infection. PLoS Pathogens 11 (4), e1004818.

Lindstedt, S., Holme, E., Lock, E.A., Hjalmarson, O., Strandvik, B., 1992. Treatment of hereditary tyrosinaemia type I by inhibition of 4-hydroxyphenylpyruvate dioxygenase. The Lancet 340 (8823), 813-817.

Lock, E.A., Ellis, M.K., Gaskin, P., Robinson, M., Auton, T.R., Provan, W.M., Smith, L.L., Prisbylla, M.P., Mutter, L.C., Lee, D.L., 1998. From toxicological problem to therapeutic use: the discovery of the mode of action of 2-(2-nitro-4-trifluoromethylbenzoyl)-1,3-cyclohexanedione (NTBC), its toxicology and development as a drug. Journal of Inherited Metabolic Disease 21 (5), 498-506.

Loenarz, C., Coleman, M.L., Boleininger, A., Schierwater, B., Holland, P.W., Ratcliffe, P.J., Schofield, C.J., 2011a. The hypoxia-inducible transcription factor pathway regulates oxygen sensing in the simplest animal, Trichoplax adhaerens. EMBO Reports 12 (1), 63-70. 
Loenarz, C., Schofield, C.J., 2008. Expanding chemical biology of 2-oxoglutarate oxygenases. Nature Chemical Biology 4, 152-156.

Loenarz, C., Schofield, C.J., 2011b. Physiological and biochemical aspects of hydroxylations and demethylations catalyzed by human 2-oxoglutarate oxygenases. Trends in biochemical sciences $36(1), 7-18$.

Macdougall, I.C., Tucker, B., Thompson, J., Tomson, C.R., Baker, L.R., Raine, A.E., 1996. A randomized controlled study of iron supplementation in patients treated with erythropoietin. Kidney International 50 (5), 1694-1699.

Marks, E., Goggins, B.J., Cardona, J., Cole, S., Minahan, K., Mateer, S., Walker, M.M., Shalwitz, R., Keely, S., 2015. Oral delivery of prolyl hydroxylase inhibitor: AKB-4924 promotes localized mucosal healing in a mouse model of colitis. Inflammatory Bowel Disease 21 (2), 267-275.

Masson, N., Ratcliffe, P.J., 2014. Hypoxia signaling pathways in cancer metabolism: the importance of co-selecting interconnected physiological pathways. Cancer and Metabolism 2 (1), 3.

Maxwell, P.H., Ferguson, D.J., Nicholls, L.G., Johnson, M.H., Ratcliffe, P.J., 1997. The interstitial response to renal injury: fibroblast-like cells show phenotypic changes and have reduced potential for erythropoietin gene expression. Kidney International 52 (3), 715-724.

Maxwell, P.H., Osmond, M.K., Pugh, C.W., Heryet, A., Nicholls, L.G., Tan, C.C., Doe, B.G., Ferguson, D.J.P., Johnson, M.H., Ratcliffe, P.J., 1993a. Identification of the renal erythropoietin-producing cells using transgenic mice. Kidney International 44, 1149-1162.

Maxwell, P.H., Pugh, C.W., Ratcliffe, P.J., 1993b. Inducible operation of the erythropoietin 3' enhancer in multiple cell lines: evidence for a widespread oxygen sensing mechanism. Proceedings of the National Academy of Sciences, USA 90, 2423-2427.

Maxwell, P.H., Wiesener, M.S., Chang, G.-W., Clifford, S.C., Vaux, E.C., Cockman, M.E., Wykoff, C.C., Pugh, C.W., Maher, E.R., Ratcliffe, P.J., 1999. The tumour suppressor protein VHL targets hypoxia-inducible factors for oxygen-dependent proteolysis. Nature 399, 271-275.

McCullough, P.A., Barnhart, H.X., Inrig, J.K., Reddan, D., Sapp, S., Patel, U.D., Singh, A.K., Szczech, L.A., Califf, R.M., 2013. Cardiovascular toxicity of epoetin-alfa in patients with chronic kidney disease. American Journal of Nephrology 37 (6), 549-558.

McDonough, M.A., Li, V., Flashman, E., Chowdhury, R., Mohr, C., Lienard, B.M., Zondlo, J., Oldham, N.J., Clifton, I.J., Lewis, J., McNeill, L.A., Kurzeja, R.J., Hewitson, K.S., Yang, E., Jordan, S., Syed, R.S., Schofield, C.J., 2006. Cellular oxygen sensing: Crystal structure of hypoxia-inducible factor prolyl hydroxylase (PHD2). Proceedings of the National Academy of Sciences, U.S.A. 103 (26), 9814-9819.

McDonough, M.A., Loenarz, C., Chowdhury, R., Clifton, I.J., Schofield, C.J., 2010. Structural studies on human 2-oxoglutarate dependent oxygenases. Current Opinion in Structural Biology 20 (6), 659672.

McDonough, M.A., McNeill, L.A., Tilliet, M., Papamicael, C.A., Chen, Q.Y., Banerji, B., Hewitson, K.S., Schofield, C.J., 2005. Selective inhibition of factor inhibiting hypoxia-inducible factor. Journal of the American Chemical Society 127 (21), 7680-7681.

McNeill, L.A., Bethge, L., Hewitson, K.S., Schofield, C.J., 2005a. A fluorescence-based assay for 2oxoglutarate-dependent oxygenases. Analytical Biochemistry 336 (1), 125-131.

McNeill, L.A., Flashman, E., Buck, M.R., Hewitson, K.S., Clifton, I.J., Jeschke, G., Claridge, T.D., Ehrismann, D., Oldham, N.J., Schofield, C.J., 2005b. Hypoxia-inducible factor prolyl hydroxylase 2 has a high affinity for ferrous iron and 2-oxoglutarate. Mol Biosyst 1 (4), 321-324.

McNeill, L.A., Hewitson, K.S., Claridge, T.D., Seibel, J.F., Horsfall, L.E., Schofield, C.J., 2002. Hypoxiainducible factor asparaginyl hydroxylase $(\mathrm{FIH}-1)$ catalyses hydroxylation at the beta-carbon of asparagine-803. Biochemical Journal 367 (Pt 3), 571-575.

Meanwell, N.A., 2011. Synopsis of some recent tactical application of bioisosteres in drug design. Journal of Medicinal Chemistry 54 (8), 2529-2591. 
Minamishima, Y.A., Moslehi, J., Bardeesy, N., Cullen, D., Bronson, R.T., Kaelin, W.G., Jr., 2008. Somatic inactivation of the PHD2 prolyl hydroxylase causes polycythemia and congestive heart failure. Blood 111 (6), 3236-3244.

Minamishima, Y.A., Moslehi, J., Padera, R.F., Bronson, R.T., Liao, R., Kaelin, W.G., Jr., 2009. A feedback loop involving the Phd3 prolyl hydroxylase tunes the mammalian hypoxic response in vivo. Molecular and Cellular Biology 29 (21), 5729-5741.

Mole, D.R., Schlemminger, I., McNeill, L.A., Hewitson, K.S., Pugh, C.W., Ratcliffe, P.J., Schofield, C.J., 2003. 2-oxoglutarate analogue inhibitors of HIF prolyl hydroxylase. Bioorganic \& Medicinal Chemistry Letters 13, 2677-2680.

Moran, G.R., 2005. 4-Hydroxyphenylpyruvate dioxygenase. Archives of Biochemistry and Biophysics $433(1), 117-128$.

Morinet, F., Casetti, L., Francois, J.H., Capron, C., Pillet, S., 2013. Oxygen tension level and human viral infections. Virology 444 (1-2), 31-36.

Myllyharju, J., 2013. Prolyl 4-hydroxylases, master regulators of the hypoxia response. Acta Physiologica (Oxford) 208 (2), 148-165.

Nizet, V., Johnson, R.S., 2009. Interdependence of hypoxic and innate immune responses. Nature Reviews Immunology 9 (9), 609-617.

Noma, A., Ishitani, R., Kato, M., Nagao, A., Nureki, O., Suzuki, T., 2010. Expanding role of the jumonji C domain as an RNA hydroxylase. Journal of Biological Chemistry 285 (45), 34503-34507.

Nwogu, N.I., Greenen, D., Bean, M., Brenner, M.C., Huang, X., Buttrick, P.M., 2001. Inhibition of collagen synthesis with prolyl 4-hydroxylase inhibitor improves left ventricular function and alters the pattern of left ventricular dilatation after myocardial infarction. Circulation 104, 22162221.

Oehme, F., Jonghaus, W., Naurouz-Ott, L., Huetter, J., Flamme, I., 2004. A non-radioactive 96-well plate assay for the detection of hypoxia-inducible factor prolyl hydroxylase activity. Analytical Biochemistry 330, 74-80.

Okumura, C.Y., Hollands, A., Tran, D.N., Olson, J., Dahesh, S., von Kockritz-Blickwede, M., Thienphrapa, W., Corle, C., Jeung, S.N., Kotsakis, A., Shalwitz, R.A., Johnson, R.S., Nizet, V., 2012. A new pharmacological agent (AKB-4924) stabilizes hypoxia inducible factor-1 (HIF-1) and increases skin innate defenses against bacterial infection. Journal of Molecular Medicine 90 (9), 1079 1089.

Olson, E., Demopoulos, L., Haws, T.F., Hu, E., Fang, Z., Mahar, K.M., Qin, P., Lepore, J., Bauer, T.A., Hiatt, W.R., 2014. Short-term treatment with a novel HIF-prolyl hydroxylase inhibitor (GSK1278863) failed to improve measures of performance in subjects with claudication-limited peripheral artery disease. Vascular medicine 19 (6), 473-482.

Ong, S.G., Lee, W.H., Theodorou, L., Kodo, K., Lim, S.Y., Shukla, D.H., Briston, T., Kiriakidis, S., Ashcroft, M., Davidson, S.M., Maxwell, P.H., Yellon, D.M., Hausenloy, D.J., 2014. HIF-1 reduces ischaemiareperfusion injury in the heart by targeting the mitochondrial permeability transition pore. Cardiovascular Research 104 (1), 24-36.

Pektas, S., Taabazuing, C.Y., Knapp, M.J., 2015. Increased Turnover at Limiting 02 Concentrations by the Thr(387) --> Ala Variant of HIF-Prolyl Hydroxylase PHD2. Biochemistry 54 (18), 2851-2857.

Philipp, S., Jurgensen, J.S., Fielitz, J., Bernhardt, W.M., Weidemann, A., Schiche, A., Pilz, B., Dietz, R., Regitz-Zagrosek, V., Eckardt, K.U., Willenbrock, R., 2006. Stabilization of hypoxia inducible factor rather than modulation of collagen metabolism improves cardiac function after acute myocardial infarction in rats. European Journal of Heart Failure 8 (4), 347-354.

Pollard, P.J., Briere, J.J., Alam, N.A., Barwell, J., Barclay, E., Wortham, N.C., Hunt, T., Mitchell, M., Olpin, S., Moat, S.J., Hargreaves, I.P., Heales, S.J., Chung, Y.L., Griffiths, J.R., Dalgleish, A., McGrath, J.A., Gleeson, M.J., Hodgson, S.V., Poulsom, R., Rustin, P., Tomlinson, I.P., 2005. Accumulation of Krebs cycle intermediates and over-expression of HIF1alpha in tumours which result from germline FH and SDH mutations. Human Molecular Genetics 14 (15), 2231-2239. 
Pollard, P.J., Loenarz, C., Mole, D.R., McDonough, M.A., Gleadle, J.M., Schofield, C.J., Ratcliffe, P.J., 2008. Regulation of Jumonji-domain containing histone demethylases by hypoxia inducible factor (HIF) 1-alpha. Biochemical Journal 416, 387-394.

Poppe, L., Tegley, C.M., Li, V., Lewis, J., Zondlo, J., Yang, E., Kurzeja, R.J., Syed, R., 2009. Different modes of inhibitor binding to prolyl hydroxylase by combined use of X-ray crystallography and NMR spectroscopy of paramagnetic complexes. Journal of the American Chemical Society 131 (46), 16654-16655.

Pouyssegur, J., Dayan, F., Mazure, N.M., 2006. Hypoxia signalling in cancer and approaches to enforce tumour regression. Nature 441 (7092), 437-443.

Prabhakar, N.R., Semenza, G.L., 2012. Adaptive and maladaptive cardiorespiratory responses to continuous and intermittent hypoxia mediated by hypoxia-inducible factors 1 and 2 . Physiological Reviews 92 (3), 967-1003.

Reischl, S., Li, L., Walkinshaw, G., Flippin, L.A., Marti, H.H., Kunze, R., 2014. Inhibition of HIF prolyl-4hydroxylases by FG-4497 reduces brain tissue injury and edema formation during ischemic stroke. PLoS One 9 (1), e84767.

Robinson, A., Keely, S., Karhausen, J., Gerich, M.E., Furuta, G.T., Colgan, S.P., 2008. Mucosal protection by hypoxia-inducible factor prolyl hydroxylase inhibition. Gastroenterology 134 (1), 145-155.

Roda, J.M., Wang, Y., Sumner, L.A., Phillips, G.S., Marsh, C.B., Eubank, T.D., 2012. Stabilization of HIF2alpha induces sVEGFR-1 production from tumor-associated macrophages and decreases tumor growth in a murine melanoma model. Journal of immunology 189 (6), 3168-3177.

Rose, N.R., McDonough, M.A., King, O.N., Kawamura, A., Schofield, C.J., 2011. Inhibition of 2oxoglutarate dependent oxygenases. Chem Soc Rev 40 (8), 4364-4397.

Rosenberger, C., Mandriota, S.J., Jurgensen, J.S., Wiesener, M.S., Horstrup, J.H., Frei, U., Ratcliffe, P.J., Maxwell, P.H., Bachmann, S., Eckardt, K.U., 2002. Expression of hypoxia-inducible factor-1 $\alpha$ and $-2 \alpha$ in hypoxic and ischemic rat kidneys. Journal of the American Society of Nephrology 13, 1721-1732.

Rosenberger, C., Rosen, S., Shina, A., Frei, U., Eckardt, K.U., Flippin, L.A., Arend, M., Klaus, S.J., Heyman, S.N., 2008. Activation of hypoxia-inducible factors ameliorates hypoxic distal tubular injury in the isolated perfused rat kidney. Nephrology Dialysis Transplantation 23 (11), 3472-3478.

Schödel, J., Mole, D.R., Ratcliffe, P.J., 2013. Pan-genomic binding of hypoxia-inducible transcription factors. Biological chemistry 394 (4), 507-517.

Schofield, C.J., Ratcliffe, P.J., 2004. Oxygen sensing by HIF hydroxylases. Nature Reviews Molecular Cell Biology 5, 343-354.

Schuster, S.J., Badiavas, E.V., Costa-Giomi, P., Weinmann, R., Erslev, A.J., Caro, J., 1989. Stimulation of erythropoietin gene transcription during hypoxia and cobalt exposure. Blood 73, 13-16.

Selak, M.A., Armour, S.M., MacKenzie, E.D., Boulahbel, H., Watson, D.G., Mansfield, K.D., Pan, Y., Simon, M.C., Thompson, C.B., Gottlieb, E., 2005. Succinate links TCA cycle dysfunction to oncogenesis by inhibiting HIF-alpha prolyl hydroxylase. Cancer Cell 7 (1), 77-85.

Semenza, G.L., Wang, G.L., 1992. A nuclear factor induced by hypoxia via de novo protein synthesis binds to the human erythropoietin gene enhancer at a site required for transcriptional activation. Molecular and Cellular Biology 12, 5447-5454.

Shah, Y.M., Xie, L., 2014. Hypoxia-Inducible Factors Link Iron Homeostasis and Erythropoiesis. Gastroenterology 146 (3), 630-642.

Sharir, M., Zimmerman, T.J., 1993. In vitro inhibition of collagen formation by 2,4-pyridine dicarboxylate and minoxidil in rabbit corneal fibroblasts. Current eye research 12 (6), 553-559.

Siddiq, A., Ayoub, I.A., Chavez, J.C., Aminova, L., Shah, S., LaManna, J.C., Patton, S.M., Connor, J.R., Cherny, R.A., Volitakis, I., Bush, A.I., Langsetmo, I., Seeley, T., Gunzler, V., Ratan, R.R., 2005. Hypoxia-inducible factor prolyl 4-hydroxylase inhibition. A target for neuroprotection in the central nervous system. Journal of Biological Chemistry 280 (50), 41732-41743.

Simkhovich, B.Z., Shutenko, Z.V., Meirena, D.V., Khagi, K.B., Mezapuke, R.J., Molodchina, T.N., Kalvins, I.J., Lukevics, E., 1988. 3-(2,2,2-Trimethylhydrazinium)propionate (THP)--a novel gamma- 
butyrobetaine hydroxylase inhibitor with cardioprotective properties. Biochem Pharmacol 37 (2), 195-202.

Simmons, D.L., Botting, R.M., Hla, T., 2004. Cyclooxygenase isozymes: the biology of prostaglandin synthesis and inhibition. Pharmacological reviews 56 (3), 387-437.

Singh, A.K., Mukhopadhyay, C., Biswas, S., Singh, V.K., Mukhopadhyay, C.K., 2012. Intracellular pathogen Leishmania donovani activates hypoxia inducible factor-1 by dual mechanism for survival advantage within macrophage. PLoS One 7 (6), e38489.

Smirnova, N.A., Rakhman, I., Moroz, N., Basso, M., Payappilly, J., Kazakov, S., Hernandez-Guzman, F., Gaisina, I.N., Kozikowski, A.P., Ratan, R.R., Gazaryan, I.G., 2010. Utilization of an in vivo reporter for high throughput identification of branched small molecule regulators of hypoxic adaptation. Chemistry \& biology 17 (4), 380-391.

Snell, C.E., Turley, H., Mclntyre, A., Li, D., Masiero, M., Schofield, C.J., Gatter, K.C., Harris, A.L., Pezzella, F., 2014. Proline-hydroxylated hypoxia-inducible factor 1alpha (HIF-1alpha) upregulation in human tumours. PLoS One 9 (2), e88955.

Song, D., Li, L.S., Arsenault, P.R., Tan, Q., Bigham, A.W., Heaton-Johnson, K.J., Master, S.R., Lee, F.S., 2014. Defective Tibetan PHD2 binding to p23 links high altitude adaption to altered oxygen sensing. Journal of Biological Chemistry 289 (21), 14656-14665.

Souma, T., Nezu, M., Nakano, D., Yamazaki, S., Hirano, I., Sekine, H., Dan, T., Takeda, K., Fong, G.H., Nishiyama, A., Ito, S., Miyata, T., Yamamoto, M., Suzuki, N., 2015. Erythropoietin Synthesis in Renal Myofibroblasts Is Restored by Activation of Hypoxia Signaling. Journal of the American Society of Nephrology In Press.

Souma, T., Yamazaki, S., Moriguchi, T., Suzuki, N., Hirano, I., Pan, X., Minegishi, N., Abe, M., Kiyomoto, H., Ito, S., Yamamoto, M., 2013. Plasticity of renal erythropoietin-producing cells governs fibrosis. Journal of the American Society of Nephrology 24 (10), 1599-1616.

Stubbs, C.J., Loenarz, C., Mecinovic, J., Yeoh, K.K., Hindley, N., Lienard, B.M., Sobott, F., Schofield, C.J., Flashman, E., 2009. Application of a proteolysis/mass spectrometry method for investigating the effects of inhibitors on hydroxylase structure. Journal of Medicinal Chemistry 52 (9), 27992805.

Suhara, T., Hishiki, T., Kasahara, M., Hayakawa, N., Oyaizu, T., Nakanishi, T., Kubo, A., Morisaki, H., Kaelin, W.G., Jr., Suematsu, M., Minamishima, Y.A., 2015. Inhibition of the oxygen sensor PHD2 in the liver improves survival in lactic acidosis by activating the Cori cycle. Proceedings of the National Academy of Sciences, USA 112 (37), 11642-11647.

Szczech, L.A., Barnhart, H.X., Inrig, J.K., Reddan, D.N., Sapp, S., Califf, R.M., Patel, U.D., Singh, A.K., 2008. Secondary analysis of the CHOIR trial epoetin-[alpha] dose and achieved hemoglobin outcomes. Kidney International 74 (6), 791-798.

Takeda, N., O'Dea, E.L., Doedens, A., Kim, J.W., Weidemann, A., Stockmann, C., Asagiri, M., Simon, M.C., Hoffmann, A., Johnson, R.S., 2010. Differential activation and antagonistic function of HIF\{alpha\} isoforms in macrophages are essential for NO homeostasis. Genes \& Development 24 (5), 491-501.

Takeda, Y., Costa, S., Delamarre, E., Roncal, C., Leite de Oliveira, R., Squadrito, M.L., Finisguerra, V., Deschoemaeker, S., Bruyere, F., Wenes, M., Hamm, A., Serneels, J., Magat, J., Bhattacharyya, T., Anisimov, A., Jordan, B.F., Alitalo, K., Maxwell, P., Gallez, B., Zhuang, Z.W., Saito, Y., Simons, M., De Palma, M., Mazzone, M., 2011. Macrophage skewing by Phd2 haplodeficiency prevents ischaemia by inducing arteriogenesis. Nature 479 (7371), 122-126.

Tarhonskaya, H., Chowdhury, R., Leung, I.K., Loik, N.D., McCullagh, J.S., Claridge, T.D., Schofield, C.J., Flashman, E., 2014a. Investigating the contribution of the active site environment to the slow reaction of hypoxia-inducible factor prolyl hydroxylase domain 2 with oxygen. Biochemical Journal 463 (3), 363-372.

Tarhonskaya, H., Hardy, A.P., Howe, E.A., Loik, N.D., Kramer, H.B., McCullagh, J.S., Schofield, C.J., Flashman, E., 2015. Kinetic Investigations of the Role of Factor Inhibiting Hypoxia-inducible Factor (FIH) as an Oxygen Sensor. Journal of Biological Chemistry 290 (32), 19726-19742. 
Tarhonskaya, H., Rydzik, A.M., Leung, I.K., Loik, N.D., Chan, M.C., Kawamura, A., McCullagh, J.S., Claridge, T.D., Flashman, E., Schofield, C.J., 2014b. Non-enzymatic chemistry enables 2hydroxyglutarate-mediated activation of 2-oxoglutarate oxygenases. Nature communications $5,3423$.

Thalhammer, A., Aik, W., Bagg, E.A.L., Schofield, C.J., 2012. The potential of 2-oxoglutarate oxygenases acting on nucleic acids as therapeutic targets. Drug Discovery Today: Therapeutic Strategies 9 (2-3), e91-e100.

Thevis, M., Milosovich, S., Licea-Perez, H., Knecht, D., Cavalier, T., Schanzer, W., 2015. Mass spectrometric characterization of a prolyl hydroxylase inhibitor GSK1278863, its bishydroxylated metabolite, and its implementation into routine doping controls. Drug Testing and Analysis In Press.

Thinnes, C.C., England, K.S., Kawamura, A., Chowdhury, R., Schofield, C.J., Hopkinson, R.J., 2014. Targeting histone lysine demethylases - progress, challenges, and the future. Biochimica et Biophysica Acta 1839 (12), 1416-1432.

Tian, Y., Yeoh, K., Lee, M., Ericsson, T., Kessler, B., Kramer, H., Edelmann, M., William, C., Pugh, C., Schofield, C., Ratcliffe, P., 2011. Differential sensitivity of HIF hydroxylation sites to hypoxia and hydroxylase inhibitors. Journal of Biological Chemistry 286 (15), 13041-13051.

Tschank, G., Brocks, D.G., Engelbart, K., Mohr, J., Baader, E., Gunzler, V., Hanauske-Abel, M.H., 1991. Inhibition of prolyl hydroxylation and procollagen processing in chick-embryo calvaria by a derivative of pyridine-2,4-dicarboxylate. Characterization of the diethyl ester as a proinhibitor. Biochemical Journal 275, 469-476.

Unger, E.F., Thompson, A.M., Blank, M.J., Temple, R., 2010. Erythropoiesis-Stimulating Agents - Time for a Reevaluation. New England Journal of Medicine 362 (3), 189-192.

Uniacke, J., Holterman, C.E., Lachance, G., Franovic, A., Jacob, M.D., Fabian, M.R., Payette, J., Holcik, M., Pause, A., Lee, S., 2012. An oxygen-regulated switch in the protein synthesis machinery. Nature 486 (7401), 126-129.

Vogler, M., Zieseniss, A., Hesse, A.R., Levent, E., Tiburcy, M., Heinze, E., Burzlaff, N., Schley, G., Eckardt, K.U., Willam, C., Katschinski, D.M., 2015. Pre- and post-conditional inhibition of prolyl-4hydroxylase domain enzymes protects the heart from an ischemic insult. Pflügers Archiv: European Journal of Physiology In press.

Wang, G.L., Jiang, B.-H., Rue, E.A., Semenza, G.L., 1995. Hypoxia-inducible factor 1 is a basic-helixloop-helix-PAS heterodimer regulated by cellular $\mathrm{O}_{2}$ tension. Proceedings of the National Academy of Sciences, USA 92, 5510-5514.

Wang, G.L., Semenza, G.L., 1993. Desferrioxamine induces erythropoietin gene expression and hypoxia-inducible factor 1 DNA-binding activity: implications for models of hypoxia signal transduction. Blood 82 (12), 3610-3615.

Wang, Z., Schley, G., Turkoglu, G., Burzlaff, N., Amann, K.U., Willam, C., Eckardt, K.U., Bernhardt, W.M., 2012. The protective effect of prolyl-hydroxylase inhibition against renal ischaemia requires application prior to ischaemia but is superior to EPO treatment. Nephrology, dialysis, transplantation : official publication of the European Dialysis and Transplant Association European Renal Association 27 (3), 929-936.

Wetterau, M., George, F., Weinstein, A., Nguyen, P.D., Tutela, J.P., Knobel, D., Cohen Ba, O., Warren, S.M., Saadeh, P.B., 2011. Topical prolyl hydroxylase domain-2 silencing improves diabetic murine wound closure. Wound repair and regeneration : official publication of the Wound Healing Society [and] the European Tissue Repair Society 19 (4), 481-486.

Wilkins, S.E., Karttunen, S., Hampton-Smith, R.J., Murchland, I., Chapman-Smith, A., Peet, D.J., 2012. Factor inhibiting HIF (FIH) recognises distinct molecular features within hypoxia inducible factor (HIF)-alpha versus ankyrin repeat substrates. Journal of Biological Chemistry 287 (12), 87698781.

Willam, C., Maxwell, P.H., Nichols, L., Lygate, C., Tian, Y.M., Bernhardt, W., Wiesener, M., Ratcliffe, P.J., Eckardt, K.U., Pugh, C.W., 2006. HIF prolyl hydroxylases in the rat; organ distribution and 
changes in expression following hypoxia and coronary artery ligation. Journal of Molecular and Cellular Cardiology 41 (1), 68-77.

Wolf, J., Levy, I.J., 1954. Treatment of sickle cell anemia with cobalt chloride. Archives of Internal Medicine 93 (3), 387-396.

Wu, D., Potluri, N., Lu, J., Kim, Y., Rastinejad, F., 2015. Structural integration in hypoxia-inducible factors. Nature 524 (7565), 303-308.

www.astellas.com/en/corporate/news/pdf/070507 eg.pdf, Adverse Event of FG-2216 for the Treatment of Anemia.

www.astellas.com/en/corporate/news/pdf/080402 eg.pdf, The FDA Accepts the Complete Response for Clinical Holds of FG-2216*/FG-4592 for the Treatment of Anemia.

Xia, X., Lemieux, M.E., Li, W., Carroll, J.S., Brown, M., Liu, X.S., Kung, A.L., 2009. Integrative analysis of HIF binding and transactivation reveals its role in maintaining histone methylation homeostasis. Proceedings of the National Academy of Sciences, U.S.A. 106 (11), 4260-4265.

Zhou, J., Kelly, W.L., Bachmann, B.O., Gunisor, M., Townsend, C.A., Solomon, E.I., 2001. Spectroscopic studies of substrate interactions with clavaminate synthase 2, a multifunctional alpha-KG dependent non-heme iron enzyme: correlation with mechanisms and reactivities. Journal of the American Chemical Society 123, 7388-7398.

Zimmermann, A.S., Morrison, S.D., Hu, M.S., Li, S., Nauta, A., Sorkin, M., Meyer, N.P., Walmsley, G.G., Maan, Z.N., Chan, D.A., Gurtner, G.C., Giaccia, A.J., Longaker, M.T., 2014. Epidermal or dermal specific knockout of PHD-2 enhances wound healing and minimizes ischemic injury. PLoS One 9 (4), e93373. 